\title{
The Flexibility of Ectopic Lipids
}

\author{
Hannah Loher ${ }^{1}$, Roland Kreis ${ }^{2}$, Chris Boesch ${ }^{2}$ and Emanuel Christ ${ }^{1, *}$ \\ 1 Division of Endocrinology, Diabetes and Clinical Nutrition, Inselspital, Bern University Hospital, \\ University of Bern, CH-3010 Bern, Switzerland; hannah.loher@bluewin.ch \\ 2 Department of Clinical Research \& Institute of Interventional, Diagnostic and Pediatric Radiology, \\ University of Bern, CH-3010 Bern, Switzerland; roland.kreis@insel.ch (R.K.); chris.boesch@insel.ch (C.B.) \\ * Correspondence: emanuel.christ@insel.ch; Tel.: +41-31-632-40-70
}

Academic Editor: Gregor Drummen

Received: 26 June 2016; Accepted: 1 September 2016; Published: 14 September 2016

\begin{abstract}
In addition to the subcutaneous and the visceral fat tissue, lipids can also be stored in non-adipose tissue such as in hepatocytes (intrahepatocellular lipids; IHCL), skeletal (intramyocellular lipids; IMCL) or cardiac muscle cells (intracardiomyocellular lipids; ICCL). Ectopic lipids are flexible fuel stores that can be depleted by physical exercise and repleted by diet. They are related to obesity and insulin resistance. Quantification of IMCL was initially performed invasively, using muscle biopsies with biochemical and/or histological analysis. ${ }^{1} \mathrm{H}$-magnetic resonance spectroscopy $\left({ }^{1} \mathrm{H}-\mathrm{MRS}\right)$ is now a validated method that allows for not only quantifying IMCL non-invasively and repeatedly, but also assessing IHCL and ICCL. This review summarizes the current available knowledge on the flexibility of ectopic lipids. The available evidence suggests a complex interplay between quantitative and qualitative diet, fat availability (fat mass), insulin action, and physical exercise, all important factors that influence the flexibility of ectopic lipids. Furthermore, the time frame of the intervention on these parameters (short-term vs. long-term) appears to be critical. Consequently, standardization of physical activity and diet are critical when assessing ectopic lipids in predefined clinical situations.
\end{abstract}

Keywords: ectopic lipids; insulin resistance; exercise; fasting; diabetes mellitus; growth hormone deficiency; athlete's paradox; intramyocellular lipids; intrahepatocellular lipids; intracardiomyocellular lipids

\section{Introduction}

Obesity is related to the insulin resistance syndrome including type 2 diabetes mellitus, hypertension [1,2], non-alcoholic fatty liver disease (NAFLD) [3,4], and, consequently, increased risk for cardiovascular morbidity and mortality [5-7]. It has been established that besides the absolute amount of fat, its tissue-specific distribution plays a major role as a risk factor for cardiovascular disease [8].

Visceral obesity is well known to be associated with higher all-cause mortality [9]. It is also linked to increased risk for cardiovascular morbidity and mortality [10,11], as well as with type 2 diabetes [12-14]. Similarly, recent evidence suggests that the accumulation of epicardial adipose tissue around the heart is associated with coronary heart disease in humans [15].

In addition to the subcutaneous and the visceral fat tissue, lipids can also be stored in non-adipose tissues such as in hepatocytes (intrahepatocellular lipids; IHCL), skeletal (intramyocellular lipids; IMCL) or cardiac muscle cells (intracardiomyocellular lipids; ICCL), and pancreatic beta cells [16]. This fat is called ectopic fat [17]. Most importantly, the amount of visceral fat mass has been related to ectopic fat deposits [18-20], indicating an interaction between the different lipid deposits. This also implies that ectopic lipids are closely related to cardiovascular morbidity. 
The pathophysiological link between ectopic lipids and cardiovascular morbidity lies in the impaired insulin action on target tissues (liver, muscle), which is influenced by ectopic lipid deposits. The first studies investigating these relations were published ca. 20 years ago and suggested that in particular the amounts of IMCL and IHCL are related to insulin resistance [21,22]. More recent data indicate that ectopic lipids can be influenced by diet [23-42] and physical exercise [32,37,38,43-67] (i.e., lifestyle intervention).

This review focuses on ectopic lipids, in particular on the flexibility of these lipid deposits whereby the term "flexibility" is used to describe changes in the amount of ectopic lipid content following a stimulus/intervention. Data investigating the flexibility of ectopic lipids in skeletal muscle have been extensively reported $[37,38,43-55,65-68]$. However, data on the impact of an acute bout of physical exercise on IHCL and ICCL are scarce $[43,44,67,69,70]$ and not available with regard to pancreatic ectopic lipids. In addition, the underlying mechanisms of the flexibility of ectopic lipids are not completely understood.

Most of the available data regarding the flexibility of ectopic lipids in humans are based on healthy subjects (mainly males), such as sedentary lean and obese volunteers or endurance-trained athletes. Studies on the flexibility of ectopic lipids in patients are mainly limited to insulin resistant, i.e., glucose intolerant patients or patients with type 2 diabetes [71-75], but this data is mainly limited to long-term interventions. Some data exist in patients with type 1 diabetes or hypopituitarism [65-67].

The first studies that investigated the flexibility of ectopic lipids were performed using skeletal muscle biopsies before and after physical exercise [32,58-64,76-79]. Later, ${ }^{1} \mathrm{H}$-magnetic resonance spectroscopy ( ${ }^{1} \mathrm{H}-\mathrm{MRS}$ ) became a reliable tool to assess IMCL as well as IHCL and ICCL non-invasively. Hence, repeated measurements of ectopic lipids became feasible.

This review summarizes the current knowledge on the flexibility of ectopic lipids (IMCL, IHCL ICCL) in humans. The main focus is on the influencing factors of ectopic lipids, namely physical exercise and diet.

This narrative review summarizes the current knowledge on the flexibility of ectopic lipids (IMCL, IHCL ICCL) in humans. The main focus is on the influencing factors of ectopic lipids, namely physical exercise and diet. PubMed was used and the search terms were intramyocellular lipids, skeletal muscle lipids, intrahepatic fat, intrahepatocellular lipids, intracardiomycellular lipids, intramuscular triglycerides, ectopic fat, ectopic lipids, exercise, fat, diet, lipid infusion, MR-spectroscopy, and bariatric surgery.

\section{Methods to Assess Ectopic Lipids}

Ectopic lipids in skeletal muscle have been quantified for decades using biochemical analysis of muscle tissue, which was extracted through biopsies mainly from M. vastus lateralis [80]. This method has been used for quantification of IMCL in physiological and clinical studies until today [59,81-85]. Even though it has been the most widely used method, biochemical analysis of muscle tissue is inaccurate. Three simultaneous muscle biopsies in the same muscle of the same subject showed a range of $24 \%$ in triacylglycerol content [81]. Although the visible fat had been removed before biochemical analysis, it is likely that extramuscular triacylglycerol was still present in many of the samples [81], resulting in less reliable results $[81,86]$. In addition, biopsies are based on an invasive method and repeated assessment is not always feasible. However, the investigation of biopsies allows for additional information such as biochemical pathways and structural analysis using EM [86] or histological analysis using oil red O staining [21,48,60,87].

In the 1990s, a non-invasive method was introduced to measure IMCL by means of ${ }^{1} \mathrm{H}-\mathrm{MRS}$. It was first described by Schick et al. [88] and then validated and established by Boesch et al. [57,89-91]. Quantification of IMCL using ${ }^{1} \mathrm{H}$-MRS correlated well with EM analysis from biopsy samples, while biochemical analysis of biopsies was correlated neither with ${ }^{1} \mathrm{H}-\mathrm{MRS}$ nor with EM analyses [86]. The coefficient of variation of ${ }^{1} \mathrm{H}-\mathrm{MRS}$ for the assessment of IMCL is around 6\% [57].

Liver fat is usually quantified using liver biopsies [92]. Obviously, because of its invasiveness, it cannot be performed repetitively in studies with healthy volunteers, yet it is still the gold standard 
for the diagnosis of NAFLD [92]. ${ }^{1} \mathrm{H}$-MRS is a good alternative because it is a non-invasive and non-ionizing procedure that allows for the estimation of hepatic fat and may be useful in follow-ups with patients with fatty liver disease [93-96]. Studies comparing the assessment of steatosis by ${ }^{1} \mathrm{H}-\mathrm{MRS}$ and histology showed a close correlation between the two methods $[97,98]$. When measured twice, IHCL levels were highly correlated $(r=0.99)$, pointing to good reproducibility [99]. For the determination of IHCL levels above those encountered in lean healthy subjects, MR imaging with various forms of the so-called Dixon technique is also available for repeated non-invasive determination of IHCL [100].

Ectopic lipids in cardiac muscle are less investigated; however, ${ }^{1} \mathrm{H}-\mathrm{MRS}$ also provides a reliable tool [101-103] to investigate this tissue. Validation of ${ }^{1} \mathrm{H}-\mathrm{MRS}$ in cardiac muscle with biopsy has been done during heart transplantation procedures. A biopsy of the myocardium and a ${ }^{1} \mathrm{H}-\mathrm{MRS}$ measurement before heart transplantation showed a high correlation $\left(r^{2}=0.83\right)$ of in vivo and ex vivo measurements [104]. In repeated measurements using respiratory navigator gating, the correlation coefficient of 0.81 indicates a good reproducibility of ${ }^{1} \mathrm{H}-\mathrm{MRS}$ in ICCL quantification [105].

An in-depth view and critical appraisal of the ${ }^{1} \mathrm{H}-\mathrm{MRS}$ method in assessing ectopic lipids has been covered by other reviews [90] and goes beyond the scope of this article. The current review focuses on the physiological factors that influence the flexibility of ectopic lipids.

Examples for the measurement of ectopic lipids using ${ }^{1} \mathrm{H}-\mathrm{MRS}$ are shown in Figures 1-3.

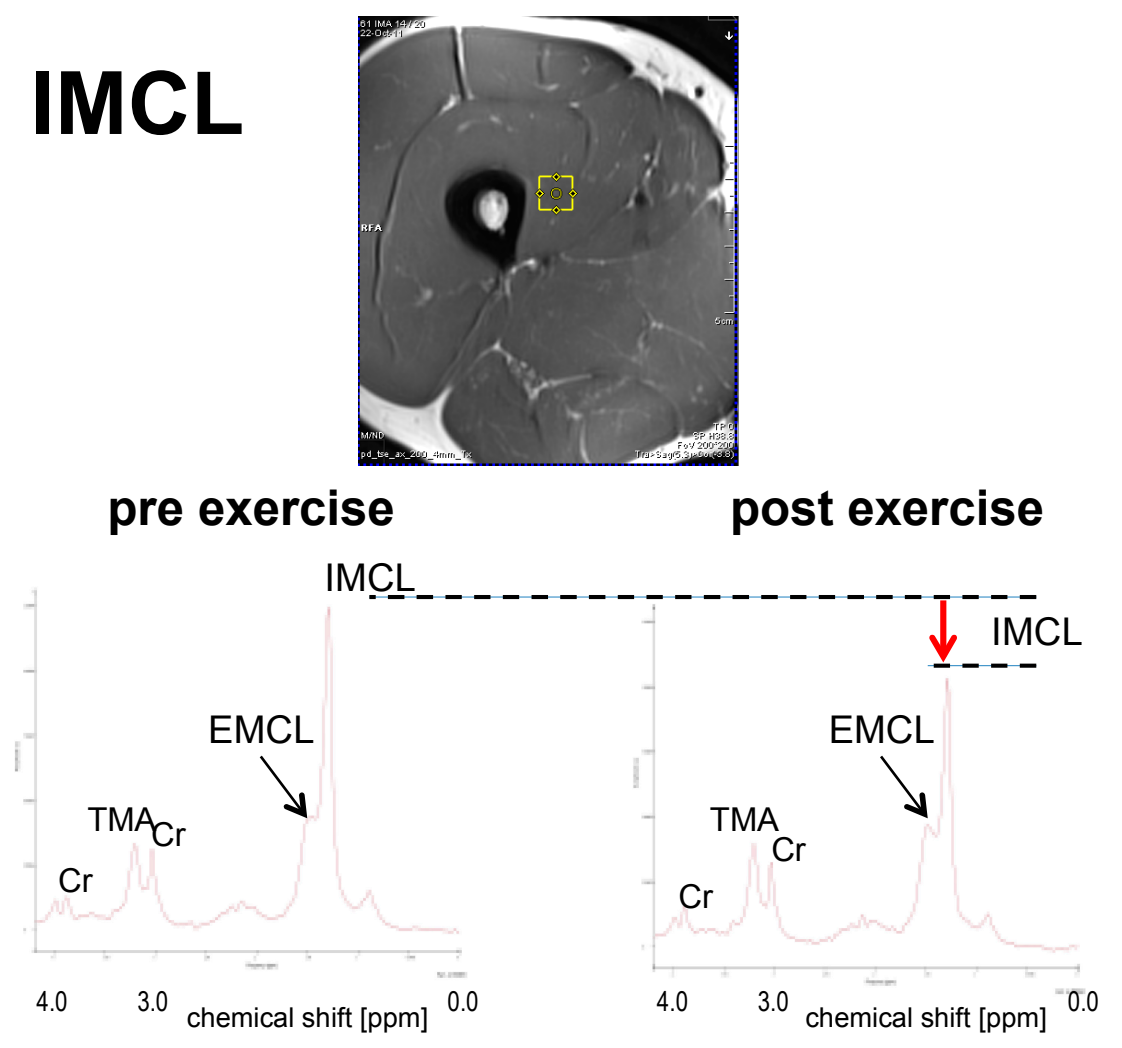

Figure 1. Sample ${ }^{1} \mathrm{H}-\mathrm{MR}$ spectra for the quantification of IMCL obtained from $\mathrm{m}$. vastus intermedius before and after an exercise bout of $2 \mathrm{~h}$ : The largest peak in the spectrum originates from the aliphatic methylene groups in the fatty acid chains of IMCL. Direct comparison of the pre- and post-exercise spectra shows that IMCL were consumed in the exercise. Other peaks originate from further protons on the IMCL lipid chains, but also from the partially overlapping spectrum of extramyocellular lipids (EMCL, see e.g., [90] for details), as well as creatines ( $\mathrm{CH} 2$ at $3.9 \mathrm{ppm}$ and $\mathrm{CH} 3$ at $3.0 \mathrm{ppm}$ ) and trimethyl-ammonium (TMA) groups from metabolites, like carnitine, or the phosphocholines. (For details of the acquisition methods, see the electronic supplement to [43]; in short: single volume $\left(\sim 1.5 \mathrm{~cm}^{3}\right)$, double spin echo localization, echo time $\left.30 \mathrm{~ms}, 3 \mathrm{~T}\right)$. The spin-echo image above the spectra shows the typical location where the spectra were obtained. 

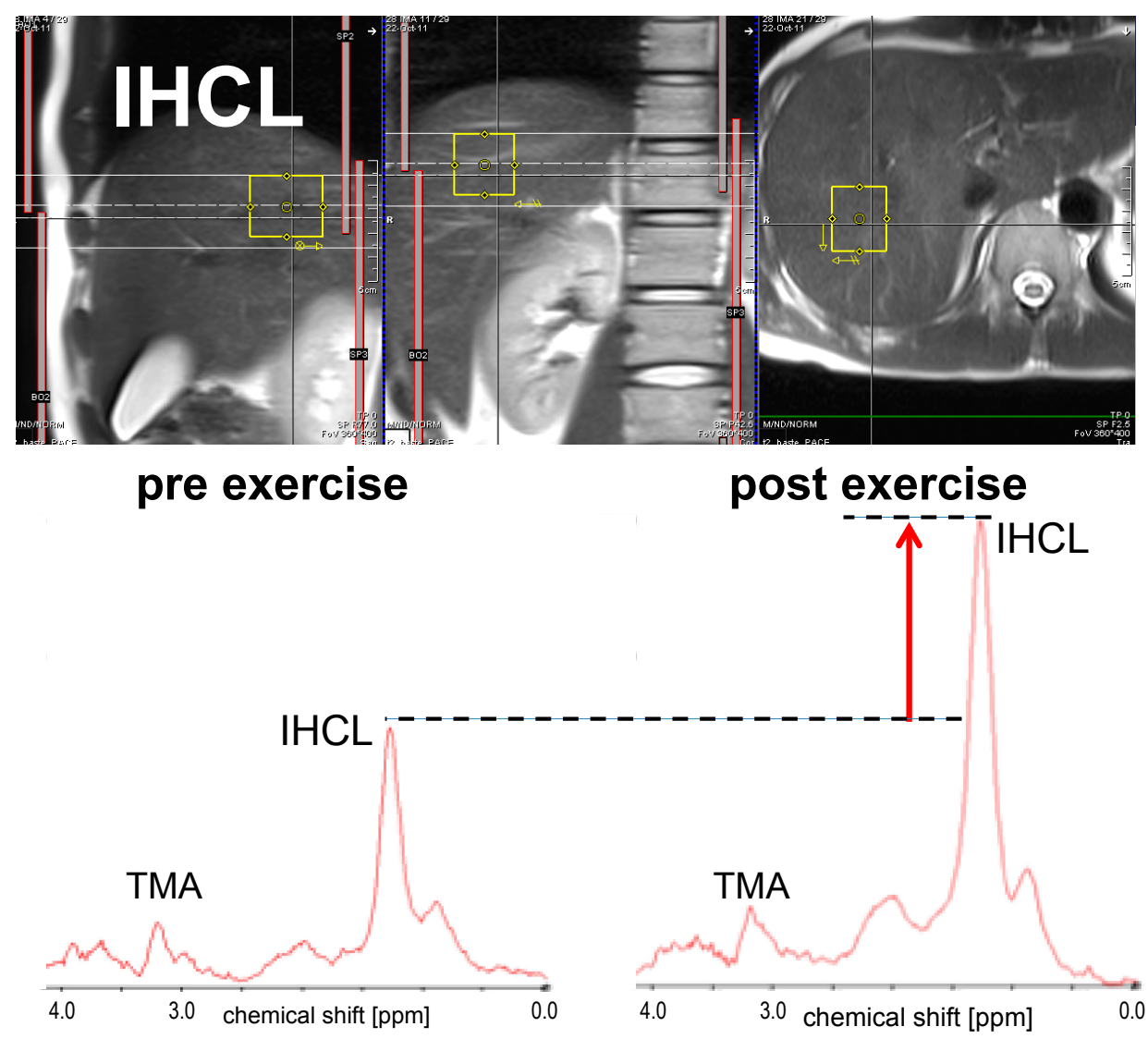

Figure 2. Sample ${ }^{1} \mathrm{H}-\mathrm{MR}$ spectra for the quantification of IHCL obtained before and after an exercise bout of $2 \mathrm{~h}$ : The largest peak in the spectrum originates from the aliphatic methylene groups in the fatty acid chains of IHCL. Direct comparison of the pre- and post-exercise spectra shows that IHCL were built up during/after the exercise. Other peaks originate from further protons on the IHCL lipid chains, and trimethyl-ammonium (TMA) groups from metabolites, like betain, or the phosphocholines (for details of the acquisition methods, see [43]; in short: single volume $\left(\sim 19 \mathrm{~cm}^{3}\right)$, stimulated echo localization, echo time $13 \mathrm{~ms}, 3 \mathrm{~T}$, spectra obtained in sync with respiration, triggered for acquisition in expiration). The spin-echo images above the spectra that had also been obtained in expiration show the typical location where the spectra were obtained.

The examples were drawn from a recent study on the flexibility of ectopic lipids as a consequence of short-term exercise [43]. They represent spectra from skeletal muscle (vastus lateralis, Figure 1), the liver (Figure 2), and the heart (cardiac septum, Figure 3), obtained from single subjects before and immediately after an exercise bout. Dashed lines and arrows represent the changes in lipid levels graphically, while model-fitting evaluations must be used for quantitative measures (often with the use of the tissue water signal as a calibration standard). The presented examples were obtained with single volume MRS methods (for acquisition parameters see details in the figure legends), but other methodology that may give information from multiple locations simultaneously (see e.g., [106] for skeletal muscle, [107] for the liver, [108] for the heart) can be used as well. 

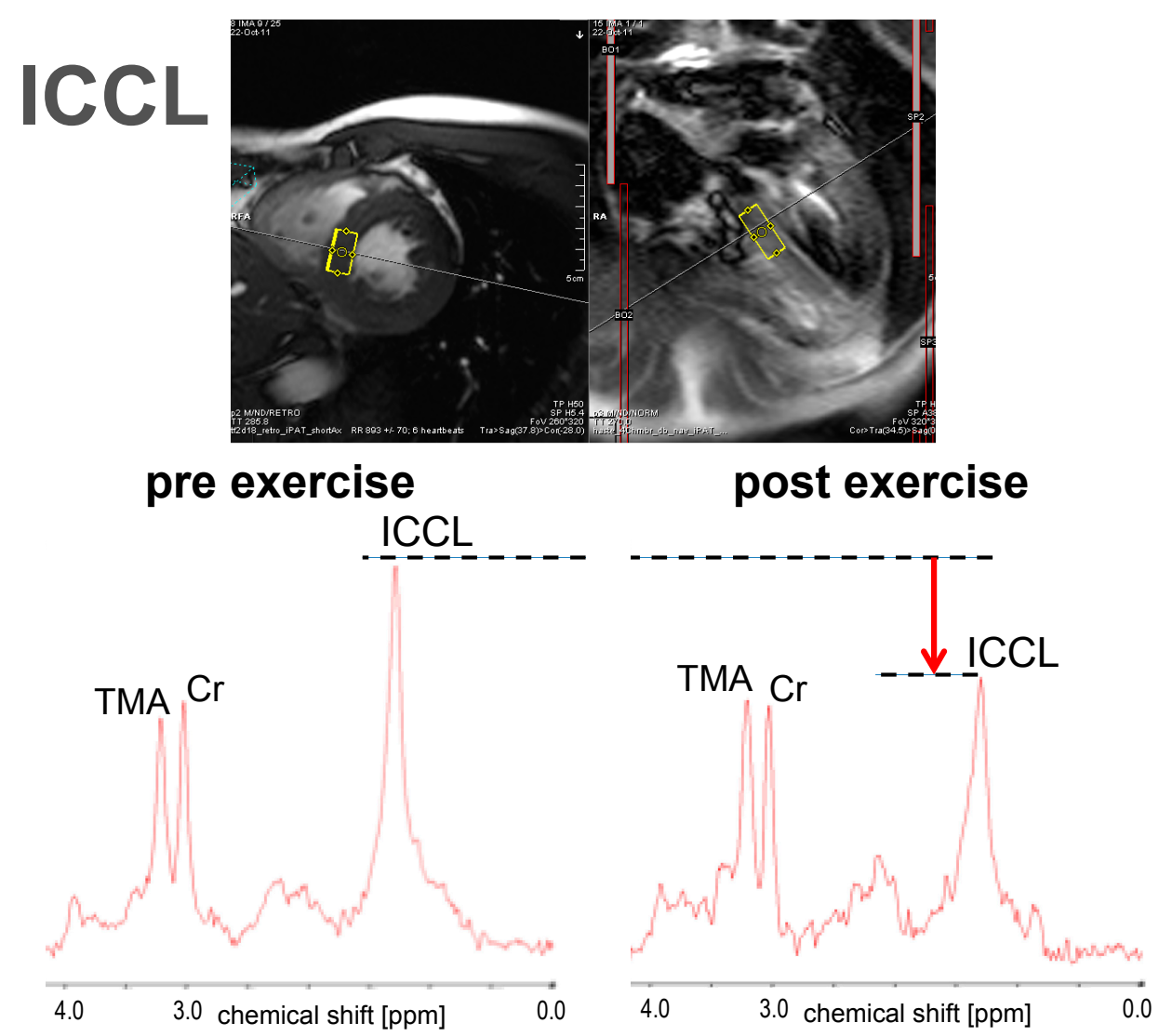

Figure 3. Sample ${ }^{1} \mathrm{H}-\mathrm{MR}$ spectra for the quantification of ICCL obtained before and after an exercise bout of $2 \mathrm{~h}$ : The largest peak in the pre-exercise spectrum originates from the aliphatic methylene groups in the fatty acid chains of ICCL. Direct comparison of the pre- and post-exercise spectra shows that ICCL were consumed during/after the exercise. Other peaks originate from further protons on the ICCL lipid chains, and creatines $\left(\mathrm{CH}_{2}\right.$ at $3.9 \mathrm{ppm}$ and $\mathrm{CH}_{3}$ at $\left.3.0 \mathrm{ppm}\right)$ and trimethyl-ammonium (TMA) groups from metabolites, like carnitine, or the phosphocholines. (For details of the acquisition methods, see [43]; in short: single volume $\left(\sim 5 \mathrm{~cm}^{3}\right)$, double spin echo localization, echo time $35 \mathrm{~ms}$, 3T, spectra obtained in sync with respiration and the cardiac cycle, triggered for acquisition in both expiration (based on realtime MR-images) and in end-systole (derived from the ECG signal)). The spin-echo images above the spectra that had also been obtained with double triggering and in the same respiratory and cardiac phase show the typical location where the spectra were obtained.

\section{The Effect of Physical Exercise on Ectopic Lipids}

The effect of physical exercise on ectopic fat, especially on IMCL, has been evaluated in several clinical studies [32,37-39,43-56,58-68,71-79,83-85,109-127]. There is evidence for an acute "pre-post-exercise" as well as a long-term "training" effect of exercise on IMCL.

\subsection{Short-Term Effect: Single Bout of Exercise}

Consistently, ${ }^{1}$ H-MRS $[37,38,43-57,65-68]$ and biopsy measurements $[21,32,58-64,77-79]$ have shown that IMCL decrease after acute short-term exercise ( $45 \mathrm{~min}-3 \mathrm{~h}$ ) at $50 \%-90 \% \mathrm{VO}_{2}$ max in healthy subjects [32,43-46], endurance-trained athletes [21,37,38,46-64], patients with type 1 diabetes [65], and hypopituitary patients with growth hormone deficiency before and after growth hormone replacement therapy $[66,67]$. Not only aerobic endurance exercise but also resistance exercises decreased IMCL $[78,127]$. These results indicate that IMCL can be considered as a flexible fuel store that is depleted after physical exercise.

The particular interest in studying patients with hormone disorders lies in the fact that hormones regulate metabolism. Insulin is a strong inhibitor of lipolysis [128], whereas growth hormone increases 
lipolysis [129-131]. During physical exercise, insulin secretion decreases and growth hormone and catecholamine secretion increases, resulting in an increase in free fatty acids' (FFA) concentration in the plasma. This is paralleled by an increase in fat availability within the working tissues such as skeletal muscle and heart muscle [43]. Patients with type 1 diabetes are an interesting model since glucose and insulin levels can be manipulated, thereby investigating carbohydrate, protein, and fat metabolism (locally and systemically) in the presence of high glucose and low insulin levels or euglycemia and high insulin levels (clamp). Similarly, hypopituitary patients with growth hormone deficiency are an ideal clinical situation to examine the potential role of growth hormone in regulating the systemic availability of FFA, thereby influencing the flexibility of ectopic lipids.

\subsubsection{IMCL}

Studies on the effect of an acute bout of physical exercise on IMCL using ${ }^{1} \mathrm{H}-\mathrm{MRS}$ are summarized in Table 1. The decrease in IMCL during a single bout of exercise was present in almost all trials $[37,38,43-55,65-67]$.

Most importantly, exercise protocols have to be designed in such a way that lipolysis is stimulated in order to induce a decrease in IMCL, meaning that exercise length and intensity need to be chosen accordingly. Differences in stimulation of lipolysis can impact on the changes in IMCL after exercise [56].

Quantitatively, stable isotope turnover studies suggest that up to $34 \%$ of the energy during exercise originates from non-free fatty acid oxidation in endurance-trained men and untrained humans $[109,132]$, i.e., from IMCL and potentially also from VLDL since the stable isotope technique cannot distinguish between different sources of triglyceride oxidation.

The results are conflicting in exercise studies using skeletal muscle biopsies $[81,82,85,110,111,133,134]$. This may be due to methodological issues since biochemical analysis has a high between-biopsy variance [81]. Alternatively, different exercise protocols may account for the different findings.

The IMCL dynamics has been extensively investigated in healthy trained males $[32,37,43,46,48,50-53,55,56,58-65,77-79,109,127]$. In contrast, results on the effect of physical exercise on ectopic lipids in females are scarce [38,45,49,121,135-137]. The limited data, however, suggest that the capacity to deplete IMCL during prolonged exercise in sedentary subjects is higher in females than in males [121,135-137]. This might be due to the higher pre-exercise IMCL content in women [121,135-138]. It was shown that total body fat is highly correlated with IMCL content in sedentary subjects $[139,140]$. Since females are known to have higher total body fat, which could partly explain the higher pre-exercise IMCL in females. However, the results are not consistent in several studies $[45,49,141]$. With regard to the influence of gender on the flexibility of IMCL, Zehnder et al. showed a higher IMCL depletion in males than in females [49] with significantly higher pre-exercise IMCL levels in males than in females. Possibly different estrogen levels during the menstrual cycle and the corresponding effect on lipolysis may contribute to these findings [142]. The gender difference in skeletal muscle substrate metabolism on the molecular level is well known and is reviewed in [112].

Most of the data are based on healthy subjects. However, there are preliminary data in patients with growth hormone deficiency and type 1 diabetes, suggesting that IMCL do not behave differently in these clinical situations [65-67].

Mechanistically, during an acute bout of exercise the energy demand is increased. This energy is provided by glycolysis of glucose/glycogen or oxidation of fatty acids. The fatty acids are supplied either by intracellular lipolysis or by uptake of fatty acids from the blood stream. In the blood stream, triglycerides are transported within very low density lipoproteins (VLDLs) or chylomicrons and FFAs are bound to albumin. The triglycerides within the VLDLs or chylomicrons are hydrolyzed to FFA, a reaction catalyzed by the lipoprotein lipase. Lipoprotein lipase is mainly expressed in the endothelium of myocytes, cardiomyocytes and adipocytes $[143,144]$. The uptake of the corresponding FFAs to the skeletal or heart muscle are facilitated by specific FFA transporters (CD36, fatty acid transport protein, FABPpm) $[145,146]$ but passive diffusion has also been reported [147]. 
Table 1. Effect of short-term exercise on IMCL using ${ }^{1} \mathrm{H}-\mathrm{MR}-\mathrm{Spectroscopy}$.

\begin{tabular}{|c|c|c|c|c|c|c|c|c|}
\hline Author (Year) & $n$ & Subjects & Gender & Intervention & IMCL & $\%$ Change & Muscle Investigated & Comments \\
\hline Christ (2016) [67] & 10 & $\begin{array}{l}\text { Volunteers with } \\
\text { adult-onset } \\
\text { GHD }\end{array}$ & $\mathrm{m}, \mathrm{f}$ & $\begin{array}{l}2 \mathrm{~h} \text { exercise at } 50 \%-60 \% \\
\mathrm{VO}_{2} \text { max on a treadmill }\end{array}$ & $\downarrow^{*}$ & -9.3 to -13.5 & M. tibialis anterior & $\begin{array}{l}\text { No significant effect of } \\
\text { growth hormone } \\
\text { replacement therapy on } \\
\text { IMCL and IHCL, IHCL } \uparrow *\end{array}$ \\
\hline Bucher (2014) [43] & 10 & $\begin{array}{l}\text { Healthy } \\
\text { volunteers }\end{array}$ & $\mathrm{m}$ & $\begin{array}{l}2 \mathrm{~h} \text { exercise on bicycle } \\
\text { ergometer at } 50 \%-60 \% \\
\qquad \mathrm{VO}_{2} \max \end{array}$ & $\downarrow^{*}$ & -16.8 & M. vastus intermedius & $\mathrm{IHCL} \uparrow *$ ICCL $\downarrow$ * \\
\hline Egger (2013) [44] & 18 & $\begin{array}{c}\text { Healthy } \\
\text { volunteers }\end{array}$ & $\mathrm{m}, \mathrm{f}$ & $\begin{array}{l}2 \mathrm{~h} \text { exercise on treadmill } \\
\text { at } 50 \%-60 \% \mathrm{VO}_{2} \max \end{array}$ & $\downarrow^{*}$ & -22.6 & M. tibialis anterior & $\operatorname{IHCL} \uparrow *$ \\
\hline Vermathen (2012) [47] & 8 & $\begin{array}{l}\text { Trained cyclists } \\
\text { or runners }\end{array}$ & $\mathrm{m}$ & $\begin{array}{c}3 \mathrm{~h} \text { exercise on bicycle } \\
\text { ergometer or treadmill at } \\
50 \% \mathrm{~W}_{\max }\end{array}$ & $\downarrow^{*}$ & -3 to -50 & $\begin{array}{l}\text { Thigh (M. vastus intermedius, } \\
\text { vastus lateralis, vastus lateralis, } \\
\text { adductor magnus, biceps femoris; } \\
\text { rectus femoris) or lower leg muscle } \\
\text { (tibialis anterior, soleus lateralis, } \\
\text { soleus medialis, gastrocnemius } \\
\text { lateralis, gastrocnemius medialis, } \\
\text { extensor digitorum) }\end{array}$ & $\begin{array}{l}\text { In } \mathrm{M} \text {. biceps femoris and } \\
\text { rectus femoris no } \\
\text { significant decrease }\end{array}$ \\
\hline Jenni (2008) [65] & 7 & $\begin{array}{c}\text { Physically } \\
\text { active men with } \\
\text { T1DM }\end{array}$ & $\mathrm{m}$ & $\begin{array}{c}2 \mathrm{~h} \text { cycling at } 55 \%-60 \% \\
\mathrm{VO}_{2} \max \end{array}$ & $\downarrow^{*}$ & -11.5 to -16.2 & M. vastus intermedius & \\
\hline Trepp (2008) [66] & 15 & $\begin{array}{l}\text { Volunteers with } \\
\text { adult-onset } \\
\text { GHD }\end{array}$ & $\mathrm{m}, \mathrm{f}$ & $\begin{array}{l}1 \mathrm{~h} \text { walking at heart rate } \\
\text { corresponding to } 50 \% \\
\mathrm{VO}_{2} \text { max, on three days } \\
\text { and low fat diet }\end{array}$ & $\downarrow^{*}$ & -35 to $-47.5^{* *}$ & M. tibialis anterior & $\begin{array}{l}\text { No significant effect of } \\
\text { growth hormone } \\
\text { replacement therapy } \\
\text { on IMCL }\end{array}$ \\
\hline De Bock (2007) [48] & 9 & $\begin{array}{l}\text { Physically } \\
\text { active men }\end{array}$ & $\mathrm{m}$ & $\begin{array}{l}2 \text { h cycling at } 75 \% \\
\mathrm{VO}_{2} \text { peak }\end{array}$ & $\downarrow^{*}$ & -47 & M. vastus lateralis & \\
\hline Zehnder (2006) [37] & 11 & $\begin{array}{l}\text { Endurance } \\
\text { trained cyclists }\end{array}$ & $\mathrm{m}$ & $3 \mathrm{~h}$ cycling at $50 \% \mathrm{~W}_{\max }$ & $\downarrow^{*}$ & -21 to -41 & M. vastus intermedius & \\
\hline Zehnder (2005) [49] & 18 & $\begin{array}{l}\text { Cyclists or } \\
\text { triathletes }\end{array}$ & $\mathrm{m}, \mathrm{f}$ & $3 \mathrm{~h}$ cycling at $50 \% \mathrm{~W}_{\max }$ & $\downarrow^{*}$ & -42 to -59 & M. vastus intermedius & Larger reduction in males \\
\hline $\begin{array}{l}\text { Schrauwen-Hinderling } \\
\text { (2003) [50] }\end{array}$ & 8 & $\begin{array}{l}\text { Highly trained } \\
\text { cyclists }\end{array}$ & $\mathrm{m}$ & $3 \mathrm{~h}$ cycling at $55 \% \mathrm{~W}_{\max }$ & $\downarrow^{*}$ & -20.4 & M. vastus lateralis & M. biceps brachii $\uparrow *$ \\
\hline Van Loon (2003) [51] & 9 & $\begin{array}{l}\text { Endurance-trained } \\
\text { cyclists }\end{array}$ & $\mathrm{m}$ & $3 \mathrm{~h}$ cycling at $55 \% \mathrm{~W}_{\max }$ & $\downarrow^{*}$ & -21 & M. vastus lateralis & $\begin{array}{l}\text { No difference between } \\
\text { normal and low-fat diet }\end{array}$ \\
\hline
\end{tabular}


Table 1. Cont.

\begin{tabular}{|c|c|c|c|c|c|c|c|c|}
\hline Author (Year) & $n$ & Subjects & Gender & Intervention & IMCL & $\%$ Change & Muscle Investigated & Comments \\
\hline White (2003) [46] & 9 & $\begin{array}{l}\text { Moderately } \\
\text { active }\end{array}$ & $\mathrm{m}$ & $\begin{array}{l}45 \text { min cycling, intervals } \\
\text { at } 50 \% \text { and } 110 \% \text { of } \\
\text { ventilator threshold }\end{array}$ & $\downarrow^{*}$ & -38 & M. vastus lateralis & \\
\hline White (2003) [45] & 18 & $\begin{array}{l}\text { Moderately } \\
\text { active }\end{array}$ & $\mathrm{m}, \mathrm{f}$ & $\begin{array}{c}1 \text { h cycling at } 65 \% \\
\mathrm{VO}_{2} \max \end{array}$ & $\downarrow^{*}$ & -11.5 to -17.1 & M. vastus lateralis & \\
\hline Johnson (2003) [52] & 6 & $\begin{array}{l}\text { Highly trained } \\
\text { cyclists }\end{array}$ & $\mathrm{m}$ & $\begin{array}{l}3 \mathrm{~h} \text { cycling at } 70 \% \\
\mathrm{VO}_{2} \max \end{array}$ & $\downarrow^{*}$ & -57 to -64 & M. vastus lateralis & $\begin{array}{c}\text { Higher IMCL } \\
\text { degradation in low } \\
\text { carbohydrate condition }\end{array}$ \\
\hline $\begin{array}{l}\text { Larson-Meyer } \\
\text { (2002) [38] }\end{array}$ & 7 & $\begin{array}{l}\text { Well-trained } \\
\text { endurance } \\
\text { runners }\end{array}$ & $\mathrm{f}$ & $\begin{array}{l}2 \mathrm{~h} \text { running at } 65 \% \\
\mathrm{VO}_{2} \max \end{array}$ & $\downarrow^{*}$ & -25 & M. soleus & \\
\hline Brechtel (2001) [53] & 12 & $\begin{array}{l}\text { Well-trained } \\
\text { subjects }\end{array}$ & $\mathrm{m}$ & $\begin{array}{c}\text { Running: parallel design } \\
60 \%-70 \% \mathrm{VO}_{2} \max \\
80 \%-90 \% \mathrm{VO}_{2} \max \\
21 / 42 \mathrm{~km}\end{array}$ & $\downarrow$ & -10 to -42 & M. tibialis anterior, M. soleus & \\
\hline Krssak (2000) [54] & 9 & Trained subjects & $\mathrm{m}, \mathrm{f}$ & $\begin{array}{l}3-4 \text { bouts of } 45 \mathrm{~min} \text { of } \\
\text { running at } 65 \%-70 \% \text { peak } \\
\text { oxygen until exhaustion }\end{array}$ & $\downarrow^{*}$ & $-33.5^{* *}$ & M. soleus & \\
\hline Rico-Sanz (2000) [55] & 5 & Trained subjects & $\mathrm{m}$ & $\begin{array}{l}90 \text { min running at } 64 \% \\
\mathrm{VO}_{2} \max \end{array}$ & $\downarrow^{*}$ & $\begin{array}{l}-15.7 \text { to } \\
-32.2^{* * *} \\
\end{array}$ & M. soleus, tibialis, gastrocnemius & $\begin{array}{l}\text { in M. gastrocnemius } \\
\text { no sign decrease }\end{array}$ \\
\hline Rico-Sanz (1998) [68] & 8 & Trained subjects & $\mathrm{m}$ & $\begin{array}{l}13.2 \mathrm{~km} \text { running, } \\
\text { jogging, sprinting }\end{array}$ & $\rightarrow$ & +9 to $-2.4 * *$ & M. soleus, gastrocnemius, tibialis & \\
\hline
\end{tabular}


The key enzymes involved in regulating lipolysis within the working tissues are the adipose triglyceride lipase [148] and the hormone sensitive lipase [149,150], which is inhibited by insulin [151] and-among others-stimulated by GH [129-131] and catecholamines [152]. Apart from the before-mentioned enzymes, other factors influence ectopic lipid degradation such as proteins coating the lipid droplets (e.g., perilipins), droplet size, and droplet localization [153].

While increased IMCL storage per se can be seen in healthy, insulin-sensitive athletes, it has also been shown that IMCL deposition in sedentary subjects can be associated with insulin resistance [154,155]. Samuel and Shulman showed an association of IMCL elevation, availability of lipotoxic intermediates, and insulin resistance [156]. It is currently unclear whether the increase in IMCL is just a consequence of insulin resistance or whether it plays an important role in the pathogenesis of mitochondrial dysfunction resulting in insulin resistance and type 2 diabetes mellitus [157]. Additionally, it is speculated that fatty acid metabolites such as diacylglycerol and ceramide play a more important role in inducing insulin resistance than triglyceride ectopic lipid deposition $[140,158]$ per se. The possible mechanisms underlying the dynamics of IMCLs are reviewed in [159].

\subsubsection{IHCL}

The clinical correlate of a pathological increase in IHCL is non-alcoholic fatty liver disease (NAFLD). NAFLD is associated with elevated mortality [160] and can evolve to an inflammation of the liver (NASH), fibrosis and then progress to cirrhosis and hepatocellular carcinoma [161]. Interestingly, type 2 diabetes is associated with a higher risk for hepatocellular carcinoma [162], which might be the consequence of a high prevalence of NAFLD in type 2 diabetes mellitus and insulin resistance [163] with an increased hepatic triglyceride synthesis in insulin resistant subjects [164]. Remarkably, elevated IHCL content is associated with hepatic insulin resistance and with peripheral insulin resistance as well [165] suggesting cross-talk between these two ectopic lipid deposits.

The few studies investigating the flexibility of IHCL following short-term exercise are summarized in Table 2.

Two studies reported a significant increase in IHCL immediately after an acute bout of physical exercise. These studies were performed in healthy trained subjects $[43,44]$, and the results are consistent with other ${ }^{1} \mathrm{H}$-MRS studies $[67,70]$. However, these results are intriguing since energy expenditure is increased during exercise and NAFLD is mainly present in non-physically active overweight subjects [4]. It is established that during physical exercise systemic lipolysis increases, consistent with an increase in systemic FFA levels [166]. The increase in FFA concentrations is compatible with the fact that FFA availability during exercise increases and exceeds the required energy of the working tissues (i.e., skeletal muscles and the heart). Consequently, the excess of FFAs is transiently stored in the liver as IHCL [167], comparable to the concept of adipose tissue as a buffer for excessive lipid availability [168]. Similarly, Shulman described the ectopic lipid deposition as a consequence of a "spillover of energy storage from adipose tissue to the liver and skeletal muscle" [169]. The fact that an increase in IMCL was also observed in non-exercising muscle [50] corroborates this hypothesis.

Johnson et al. [70] confirmed the increase in IHCL, but documented this finding only $4.5 \mathrm{~h}$ after exercise, whereas Bilet et al. did not show significant changes of IHCL following an exercise of $2 \mathrm{~h} \mathrm{[69]}$. Since the latter study was performed in overweight subjects, it is conceivable that the background IHCL was higher in this population, resulting in only small relative differences of IHCL after exercise, not detected in this study. Additionally, whether differences in dietary preloading with fat before exercise impact on the changes in IHCL remains to be established [43].

Interestingly, an increase in IHCL after exercise was also observed in subjects with growth hormone deficiency. The increase was comparable to matched control subjects. Furthermore, growth hormone replacement therapy did not affect the flexibility of IHCL [67]. This indicates that the lipolytic action of growth hormone has a negligible effect on flexibility of ectopic lipids. It is conceivable that the redundant lipolytic hormone system including cortisol and catecholamines lead to a more than sufficient lipolysis and overcomes a single hormone deficiency. 
Table 2. Effect of short-term exercise on IHCL using ${ }^{1} \mathrm{H}-\mathrm{MR}-\mathrm{Spectroscopy.}$

\begin{tabular}{|c|c|c|c|c|c|c|}
\hline Author (Year) & $n$ & Subjects & Gender & Intervention & IHCL & Comments \\
\hline Christ (2016) [67] & 10 & $\begin{array}{l}\text { Volunteers with } \\
\text { adult-onset GHD }\end{array}$ & $\mathrm{m}, \mathrm{f}$ & $\begin{array}{c}2 \mathrm{~h} \text { exercise at } 50 \%-60 \% \mathrm{VO}_{2} \\
\text { max on a treadmill }\end{array}$ & $\uparrow *$ & $\begin{array}{l}\text { No significant effect of } \\
\text { growth hormone } \\
\text { replacement therapy on } \\
\text { IMCL and IHCL, IMCL } \downarrow \text { * }\end{array}$ \\
\hline Bilet (2015) [69] & 21 & Overweight subjects & $\mathrm{m}$ & $2 \mathrm{~h}$ cycling at $50 \% \mathrm{~W}_{\max }$ & $\rightarrow$ & \\
\hline Bucher (2014) [43] & 10 & Healthy volunteers & $\mathrm{m}$ & $2 \mathrm{~h}$ cycling at $50 \%-60 \% \mathrm{VO}_{2} \max$ & $\uparrow *$ & $\mathrm{ICCL} \downarrow *$ IMCL $\downarrow$ * \\
\hline Egger (2013) [44] & 18 & Healthy volunteers & $\mathrm{m}, \mathrm{f}$ & $\begin{array}{c}2 \mathrm{~h} \text { aerobic exercise on treadmill } \\
\text { at } 50 \%-60 \% \mathrm{VO}_{2} \max \end{array}$ & $\uparrow *$ & \\
\hline Johnson (2012) [70] & 6 & Healthy trained volunteers & $\mathrm{m}$ & 90 min cycling at $65 \% \mathrm{VO}_{2}$ peak & $\uparrow *$ & At $4.5 \mathrm{~h}$ post-exercise \\
\hline
\end{tabular}

$n$ : number of subjects; IHCL: intrahepatocellular lipids comparison pre- and postexercise; *: significant ( $p<0.05)$; IMCL: intramyocellular lipids; ICCL: intracardiomyocellular lipids; MRS: ${ }^{1} \mathrm{H}-\mathrm{MR}-\mathrm{Spectroscopy}$; T1DM: Type 1 diabetes mellitus; m: male; f: female; GHD: growth hormone deficiency; $\downarrow$ : decrease; $\uparrow:$ increase; $\rightarrow:$ no change. 


\subsubsection{ICCL}

ICCL accumulation was associated with impaired cardiac function $[34,170]$ and appears to play a role in the development of diabetic cardiomyopathy, possibly mediated by lipotoxic intermediates [171].

Remarkably, Mantovani et al. recently showed that NAFLD might be associated with impaired cardiac function [172]. In addition, in non-diabetic subjects there is evidence that it is rather the increased IHCL than ICCL that correlates with diastolic dysfunction [173]. Interestingly, it is rather the pericardial fat than ICCL that correlates negatively with systolic function [174].

There are few studies investigating the effect of an acute bout of exercise on ICCL. After fat loading during three days, ICCL were significantly reduced after a two-hour bout of exercise, indicating that ICCL is also a flexible fuel store that can be used as an energy resource [43]. In contrast, Bilet et al. showed an increase in ICCL when fasting and exercising ( $2 \mathrm{~h}$ cycling) at $4 \mathrm{~h}$ after exercise while no significant change was seen when ingesting glucose during exercise with a tendency to decrease during exercise [175]. Glucose ingestion results in a release of insulin, which inhibits lipolysis and might, therefore, impact on ICCL consumption. Moreover, the diurnal variation of ICCL during a standardized day, which seems to be on the same order of magnitude as the changes induced by short-term exercise, could affect the results [101]. In conclusion, the evidence is limited and further studies are necessary.

\subsection{Long-Term Effect: Physical Exercise}

\subsubsection{IMCL}

Several studies investigated the effect of long-term (1-6 months) physical exercise on IMCL. These studies were performed in healthy trained subjects, type 2 diabetic patients, and overweight subjects.

Consistently, healthy subjects showed an increase in the absolute amount of IMCL with training $[39,62,76,85,113]$. These findings are in line with the so-called "athlete's paradox". This term was used to describe the intriguing finding that IMCL levels in athletes were as high as those in obese, sedentary subjects or insulin-resistant subjects $[114-121,158,176]$. However, the capacity to deplete IMCL during exercise was increased in endurance-trained athletes, further corroborating the fact that IMCL can be considered as local fuel stores that are used during physical exercise in proportion to their pre-exercise content $[37,45,47,56,59,62,111,135]$. It is conceivable that increased IMCL related to training are beneficial for athletes since higher substrate stores are locally available during exercise, similarly to locally stored glycogen.

There are conflicting results in subjects with type 2 diabetes mellitus or impaired glucose tolerance showing an increase in IMCL with training [71], no absolute change [73] but changes in distribution within the muscle fibers with training [72], or a reduction of IMCL with training [74,75]. Various training intensities, different training session durations, or different diet protocols may lead to this inconsistency. Interestingly, insulin sensitivity consistently improved in type 2 diabetic patients as well as in obese non-diabetic subjects following long-term exercise [72,74,177], indicating that IMCL and the flexibility of IMCL are not the only factors that determine insulin sensitivity.

Morphological difference in lipid droplets' distribution within the muscle fibers with higher subsarcolemmal lipids in insulin resistant subjects compared to highly trained subjects [72] indicate that different localization of lipid droplets within the myocyte may be critical for local lipid metabolism in trained athletes compared to insulin-resistant subjects.

\subsubsection{IHCL}

Several trials investigated the amount of IHCL following exercise training for one to six months. Some studies reported a reduction in IHCL after training intervention in healthy subjects [123,124,178-180] or type 2 diabetes patients [73]. In subjects with NAFLD, the results were conflicting with a significant decrease in IHCL following 8-16 weeks of endurance [122,181], 
high-intensity interval [182], or resistance training [183], but only a tendency to reduce IHCL after 16 weeks of aerobic exercise [125]. Remarkably, reduction in IHCL was accompanied by a higher skeletal muscle and adipose tissue insulin sensitivity but without any change in hepatic insulin sensitivity [181].

\subsubsection{ICCL}

Data on long-term interventions investigating ICCL are scarce. In type 2 diabetes, a six-month exercise intervention resulted in a reduction in paracardial fat in parallel with a reduction in visceral fat. The amount of ICCL, however, did not significantly change [73]. These findings are in agreement with another trial investigating ICCL content before and 12 weeks after a training program in overweight patients with type 2 diabetes [177]. In contrast, in obese subjects without type 2 diabetes mellitus a 12-week training intervention decreased ICCL significantly in parallel with an improved ejection fraction [126].

The reduction in paracardial fat was most likely related to the loss of whole body adipose tissue. The lack of significant changes in ICCL may be due to the fact that the heart muscle depends mainly on lipids as energy sources at baseline and during exercise [184,185]. Data on the flexibility of ICCL are limited and more studies are needed to confirm these findings.

\section{Nutritional Interventions}

\subsection{IMCL}

Studies on the effect of short-term nutritional interventions on IMCL are summarized in Table 3. Nutritional intervention studies have mainly been performed in healthy individuals. The fasting condition is associated with low insulin levels resulting in a disinhibition of lipolysis leading to an increase in fat availability as documented by an increase in FFA concentrations. This effect can even be augmented by the effect of insulin antagonists such as catecholamines, cortisol, GH, and glucagon. It is, therefore, not surprising that a fasting period of 2-5 days increased IMCL [23-26]. In contrast, a short duration fasting period $(12 \mathrm{~h})$ resulted in a decrease in IMCL; unfortunately the underlying mechanism remains unclear since information on other metabolic parameter such as FFA availability is lacking in this study [27].

When combining the effect of fasting and exercise, both inducing lipolysis, the effect on IMCL consumption during exercise is additive, meaning that IMCL breakdown during exercise in exercising skeletal muscle is increased in the fasted state [58].

On the other hand, standardized increased lipid availability in the presence of hyperinsulinemia can be induced either by an intravenous infusion of FFA paralleled by a hyperinsulinemic-euglycemic clamp or a high-fat diet with co-ingestion of carbohydrates $(\mathrm{CHO})$. In either situation hyerinsulinemia inhibits systemic and local lipolysis. 
Table 3. Effect of short-term dietary interventions on IMCL.

\begin{tabular}{|c|c|c|c|c|c|c|}
\hline Author (Year) & $n$ & Subjects & Gender & Intervention & IMCL & $\begin{array}{l}\text { Comments: Method, } \\
\text { Muscle Investigated }\end{array}$ \\
\hline Browning (2012) [23] & 18 & Healthy individuals & $\mathrm{m}, \mathrm{f}$ & Fasting for $48 \mathrm{~h}$ & $\uparrow *$ & $\begin{array}{l}{ }^{1} \mathrm{H}-\mathrm{MRS} \text { M. soleus, only in women, } \\
\text { not in men }\end{array}$ \\
\hline Green (2010) [24] & 6 & Healthy physically fit men & $\mathrm{m}$ & Fasting for $67 \mathrm{~h}$ & $\uparrow *$ & ${ }^{1} \mathrm{H}-\mathrm{MRS}$ M. vastus lateralis \\
\hline Stannard (2002) [25] & 6 & Nondiabetic, physically fit men & $\mathrm{m}$ & Fasting for $72 \mathrm{~h}$ & $\uparrow *$ & ${ }^{1} \mathrm{H}-\mathrm{MRS}$ M. vastus lateralis \\
\hline Wietek (2004) [26] & 4 & Healthy volunteers & $m, f$ & Fasting for $120 \mathrm{~h}$ & $\uparrow *$ & ${ }^{1} \mathrm{H}$-MRS M. tibialis anterior, soleus \\
\hline Machann (2011) [27] & 12 & Healthy volunteers & $\mathrm{m}$ & Fasting for $12 \mathrm{~h}$ & $\downarrow^{*}$ & ${ }^{1} \mathrm{H}$-MRS M. tibialis anterior, soleus \\
\hline Bachmann (2001) [28] & 12 & Healthy volunteers & $\mathrm{m}$ & High-fat diet for 3 days & $\uparrow *$ & $\begin{array}{c}{ }^{1} \text { H-MRS M. tibialis anterior, soleus } \\
\text { (increase in M. tibialis, not in M. soleus) }\end{array}$ \\
\hline Sakurai (2011) [29] & 37 & Healthy volunteers & $\mathrm{m}$ & Isocaloric, high-fat diet for 3 days & $\uparrow *$ & ${ }^{1} \mathrm{H}-\mathrm{MRS}$ M. tibialis anterior, M. soleus \\
\hline Zderic (2004) [30] & 6 & Endurance-trained cyclists & $\mathrm{m}$ & Isocaloric, high-fat diet for 2 days & $\uparrow *$ & Biopsy M. vastus lateralis \\
\hline Larson-Meyer (2008) [31] & 21 & Endurance-trained runners & $\mathrm{m}, \mathrm{f}$ & Isoenergetic, high-fat diet for 3 days & $\uparrow *$ & Biopsy M. vastus lateralis Sign higher \\
\hline Lindeboom (2015) [33] & 9 & Lean healthy subjects & $\mathrm{m}, \mathrm{f}$ & Single high-energy, high-fat meal & $\rightarrow$ & ${ }^{1} \mathrm{H}-\mathrm{MRS}$ M. tibialis anterior, $\uparrow * \mathrm{IHCL}$ \\
\hline Brechtel (2001) [186] & 5 & Healthy male subjects & $\mathrm{m}$ & $\begin{array}{l}5 \text { h hyperinsulinemic euglycemic } \\
\text { clamp and intralipid infusion }\end{array}$ & $\uparrow *$ & ${ }^{1} \mathrm{H}-\mathrm{MRS}$ M. tibialis anterior, M. soleus \\
\hline Bachmann (2001) [28] & 12 & Healthy volunteers & $\mathrm{m}$ & $\begin{array}{c}6 \mathrm{~h} \text { lipid infusion during } \\
\text { hyperinsulinemic euglycemic clamp }\end{array}$ & $\uparrow *$ & $\begin{array}{l}{ }^{1} \text { H-MRS M. tibialis anterior, M.soleus; } \\
\text { only in presence of insulin infusion }\end{array}$ \\
\hline Hoeks (2012) [187] & 9 & Healthy lean males & $\mathrm{m}$ & $\begin{array}{l}6 \mathrm{~h} \text { euglycemic hyperinsulinemic } \\
\text { clamp and lipid or glycerol infusion }\end{array}$ & $\uparrow *$ & $\begin{array}{l}\text { Only in long-chain triacylglycerols } \\
\text { emulsion, not in medium chain glycerols } \\
\text { emulsion Biopsy M. vastus lateralis }\end{array}$ \\
\hline Lee (2013) [188] & 28 & Normal-weight adolescents & $\mathrm{m}, \mathrm{f}$ & $\begin{array}{c}12 \mathrm{~h} \text { lipid infusion and } 3 \mathrm{~h} \\
\text { hyperinsulinemic euglycemic clamp }\end{array}$ & $\uparrow *$ & ${ }^{1} \mathrm{H}-\mathrm{MRS}$ M. tibialis anterior \\
\hline Brehm (2010) [40] & 8 & Glucose-tolerant volunteers & $\mathrm{m}$ & $\begin{array}{l}3 \mathrm{~h} \text { Euglycemic pancreatic clamp, } \\
\text { and intralipid infusion }\end{array}$ & $\rightarrow$ & ${ }^{1} \mathrm{H}-\mathrm{MRS}$ M. soleus \\
\hline
\end{tabular}

$n$ : number of subjects; IMCL: intramyocellular lipids comparison pre- and post-intervention or control diet; ${ }^{*}$ : significant ( $\left.p<0.05\right)$; IHCL: intrahepatocellular lipids; ${ }^{1} \mathrm{H}-\mathrm{MRS}$ : ${ }^{1} \mathrm{H}-\mathrm{MR}-\mathrm{Spectroscopy} ; \downarrow$ : decrease; $\uparrow:$ increase; $\rightarrow$ : no change. 
A high-fat diet for 2-3 days resulted in a significant increase in IMCL [28-31] as well as a high-fat diet for six weeks [32], whereas a single high-fat meal did not increase IMCL in lean subjects [33]. These conflicting data may be related to the amount of fat that is available to replete IMCL. A single high-fat meal results in lower fat availability compared to repetitive high-fat meals [189].

Consistently, intravenous lipid infusion of long-chain fatty acids (soybean oil) during a hyperinsulinemic-euglycemic clamp induced an increase in IMCL [28,186-188] suggesting that insulin has an important role in facilitating the repletion of IMCL. Interestingly, lipid infusion alone increased IMCL in healthy volunteers in one study [190] whereas a mixture of medium and long chain FFA did not increase IMCL in two different studies [28,40]. Importantly, with or without increase in IMCL, infusion of FFA, independent of the FFA chain length, leads to peripheral insulin resistance [187], indicating that the increase in IMCL is not the only factor that is related to peripheral insulin resistance.

Importantly, starvation (67 h) and a high-fat diet had a comparable effect on IMCL [41], probably because systemic fat availability increased in both situations.

After physical exercise, a high-fat diet replenished IMCL [24,37-39,42,191,192]. High- and low-fat diets repleted IMCLs differently after an acute bout of exercise [42], indicating that dietary fat availability following exercise is critical in repleting IMCL. However, training status (i.e., sedentary vs. endurance-trained subjects) did not significantly affect the speed of repletion [39]. Similarly, repletion of IMCL was observed in the situation of a post-exercise fasting period [54]. In this condition, the increased fat availability is related to an increase in systemic lipolysis, mainly from adipose tissue, as evidenced by an increase in FFA concentrations. A high-fat diet administered over 2.5 days before a short bout of exercise resulted in a higher pre-exercise IMCL content but also a higher reduction in IMCL [37] following exercise, indicating that local lipid fuel stores are preferentially used in case of physical exercise. Similar results were seen after low or high systemic $\mathrm{CHO}$ availability during exercise with a higher (in case of low $\mathrm{CHO}$ availability) or lower IMCL (high CHO availability) depletion, indicating that primarily $\mathrm{CHO}$ are used as fuel, if available [52]. This is consistent with the observation that IMCL decreased during exercise in fasting subjects but not in subjects ingesting $\mathrm{CHO}$ [58]. Most likely, these findings were mediated by the higher insulin levels during the CHO-rich diet, resulting in decreased lipolysis during exercise.

A calorie-restricted diet resulting in weight loss reduced overall IMCL significantly [116,193-195]. Also, an isocaloric, very low-fat diet reduced intramuscular triglyceride concentration [196]. However, when weight loss was combined with exercise training, pre-exercise IMCLs increased in the exercising muscles [116], indicating that the training effect exerts a more prominent effect on IMCL than weight reduction.

In overweight men, a high-fat diet for three weeks did not lead to IMCL accumulation [197]—in contrast to lean sedentary subjects or athletes, where a high-fat diet for 1-7 weeks increased IMCL content [191,192,198-201].

Data in patients with type 1 diabetes and hypopituitarism suggest that the flexibility of IMCL after dietary intervention is not significantly different from healthy matched control subjects $[65,66]$. However, typical insulin-resistant subjects may have decreased flexibility of IMCL [111].

In summary, short-term high fat availability induced by starvation, lipid infusion, or dietary fat intake increases IMCL, in particular in the presence of hyperinsulinemia. In contrast, long-term caloric restriction tends to reduce IMCL. The present evidence again suggests that IMCL are flexible fuel stores. However, the flexibility of IMCL is not related to insulin resistance alone, but is regulated by a complex interplay including diet, fat availability, physical exercise, and insulin action.

\subsection{IHCL}

Data on flexibility of IHCL following dietary intervention are scarce and controversial. Studies on the effect of short-term nutritional interventions on IHCL are summarized in Table 4 . A short-term very low calorie diet for three days resulted in a decrease in IHCL in men [34]; however, a fasting period of $48 \mathrm{~h}$ resulted in a significant increase in IHCL in men, but not in women [23]. 
Remarkably, the available data suggest that a high-fat meal resulted in an increase in IHCL in men. Unfortunately, data on the effect on a high-fat meal on IHCL in women are lacking $[33,35,36]$. In contrast, compared to a mixed (isocaloric) diet, a high-fat diet did not influence IHCL before a physical exercise intervention but both interventions led to an increase in IHCL after exercise [70], indicating that exercise probably exerts a more prominent effect on IHCL than a short-term diet intervention.

The long-term effect of nutrition on IHCL is mainly studied with a calorie-restricted diet for up to 16 weeks, resulting in a reduction in IHCL in healthy subjects [202-204] as well as in patients with type 2 diabetes mellitus or non-alcoholic hepatic steatosis [205-207].

In contrast, an iso- or hypercaloric high-fat diet for one to six weeks induced an IHCL accumulation in healthy normal weight [208] and overweight men [197], as well as in obese women [209]. A high-fat diet with polyunsaturated fatty acids did not affect IHCL deposition, while saturated fatty acids increased liver fat significantly [210].

However, a high-fat ( $59 \%-75 \%$ fat) hypocaloric diet for two weeks to six months resulted in a decrease in IHCL [211-213]. Surprisingly, an increase in IHCL after a high-fat diet for four days was not accompanied by an alteration in insulin sensitivity [36]. Similarly, a high-fat diet for three weeks did not affect insulin sensitivity in healthy overweight men [36,197], despite an increase in IHCL. However, in lean subjects, a high-fat diet resulted in reduced hepatic insulin sensitivity [214]. Although-in general-the amount of IHCL is positively correlated with insulin resistance (in contrast to IMCL), the relation between IHCL, the flexibility of IHCL, and insulin action is probably more complex than previously thought and more studies are needed to understand the underlying mechanisms.

Sucrose-sweetened beverages increased IHCL in overweight non-diabetic subjects and healthy subjects [215]. This is consistent with the observation that subjects with NAFLD consumed more soft drinks than healthy controls (comparable daily $\mathrm{CHO}$ intake) with a positive correlation of severity of NAFLD and amount of consumed soft drinks [216]. In general, a high-fructose diet led to an IHCL accumulation [217-220], while a reduction of consumption of sugar-sweetened beverages led to a substantial reduction in IHCL in obese subjects [221]. The increased de novo lipogenesis after a high-fructose or -glucose diet could contribute to this finding [222-225] as well as the antilipolytic effect of insulin, which is secreted after ingestion of glucose-containing drinks. The effect of fructose on IHCL was dose-dependent since a lower amount of fructose over four weeks did not affect IHCL content [226].

The effect of a high-glucose diet on IHCL was comparable to that of a high-fructose $\operatorname{diet}[217,219,227]$. Adding protein to a single meal did not blunt IHCL accumulation [33]. In contrast, when adding proteins or amino acids to a high-fat or high-fructose diet for 4-6 days, IHCL accumulation was lower without affecting insulin sensitivity $[36,220]$. When adding protein to an equilibrated diet, IHCL were significantly lowered in obese subjects [228], again without change in glucose tolerance. The underlying mechanism is unclear.

In summary, a short-term increase in fat availability by starvation, exercise, or dietary fat increased IHCL, whereas long-term starvation tended to decrease IHCL. Similar to IMCL, the current data suggest that IHCL are flexible fuel stores. IHCL are significantly related to insulin resistance, but the regulation of IHCL is a complex interplay between quantitative and qualitative diet (i.e., fat, fructose, protein), insulin action, and probably physical exercise. 
Table 4. Effect of short-term dietary interventions on IHCL using ${ }^{1} \mathrm{H}-\mathrm{MR}-\mathrm{Spectroscopy.}$

\begin{tabular}{|c|c|c|c|c|c|c|}
\hline Author (Year) & $n$ & Subjects & Gender & Intervention & IHCL & Comments \\
\hline Van der Meer (2007) [34] & 14 & Healthy, non-obese men & $\mathrm{m}$ & 3 days very low calorie diet & $\downarrow *$ & ICCL increased \\
\hline Browning (2012) [23] & 18 & Healthy individuals & $\mathrm{m}, \mathrm{f}$ & $48 \mathrm{~h}$ fasting & $\uparrow *$ & in males, no sign increase in women \\
\hline Lindeboom (2015) [33] & 9 & Lean healthy subjects & $\mathrm{m}, \mathrm{f}$ & Single high-energy, high-fat meal & $\uparrow^{*}$ & \\
\hline Van der Meer (2008) [35] & 15 & Healthy men & $\mathrm{m}$ & 3 days high-fat, high-energy diet & $\uparrow *$ & No effect on ICCL \\
\hline Bortolotti (2009) [36] & 10 & Healthy young men & $\mathrm{m}$ & 4 days hypercaloric high-fat diet & $\uparrow *$ & Protein co-ingestion blunts effect of high fat diet \\
\hline Johnson (2012) [70] & 6 & Healthy trained males & $\mathrm{m}$ & High-fat diet & $\rightarrow$ & compared to Isocaloric control diet \\
\hline Kirk (2009) [211] & 22 & Obese subjects & $\mathrm{m}, \mathrm{f}$ & 48 h energy-deficient, high-fat diet & $\downarrow *$ & \\
\hline Ngo Sock (2010) [217] & 11 & Healthy men & $\mathrm{m}$ & 7 days hypercaloric, high-fructose diet & $\uparrow *$ & \\
\hline Lê (2009) [218] & 24 & $\begin{array}{l}\text { Healthy offspring of T2DM } \\
\text { patients and control subjects }\end{array}$ & $\mathrm{m}$ & 7 days high-fructose diet & $\uparrow *$ & also significant increase in IMCL \\
\hline Lecoultre (2013) [219] & 55 & Healthy young males & $\mathrm{m}$ & 6-7 days high-fructose diet & $\uparrow *$ & Only if at least $3 \mathrm{~g}$ fructose $/ \mathrm{kg} /$ day \\
\hline Theytaz (2012) [220] & 9 & Healthy male volunteers & $\mathrm{m}$ & 6 days high-fructose diet & $\uparrow *$ & Supplementation with amino acids blunts increase \\
\hline
\end{tabular}

$n$ : number of subjects; IHCL: intrahepatocellular lipids: comparison of pre- vs. post-intervention or control diet; *: significant $(p<0.05)$; IMCL: intramyocellular lipids; ICCL: intracardiomyocellular lipids; m: male; f: female; T2DM: type 2 diabetes mellitus; $\downarrow$ : decrease; $\uparrow:$ increase; $\rightarrow$ : no change. 


\subsection{ICCL}

A high-fat diet did not affect ICCL content [35,102], even in the presence of increased serum triglyceride levels [102]. Moreover, cardiac function was not affected [35]. However, a 48-hour fasting period resulted in a significant increase in ICCL in healthy men [102]. Similarly, a short-term low-calorie diet induced a significant increase in ICCL in healthy men [34], as well as in subjects with type 2 diabetes mellitus [229]. This was likely due to the increased FFA levels during starvation or a low-calorie diet.

In contrast, a prolonged hypocaloric diet decreased ICCL [206] and improved myocardial function. However, the very low calorie diet also resulted in significantly lower blood pressure and body weight. Both of them may have a beneficial impact on myocardial function.

\subsection{Effect of Bariatric Surgery on Ectopic Lipids}

The most effective treatment on the cardiometabolic risk profile is bariatric surgery. Data on the effect of bariatric surgery on ectopic lipids are scare. The current evidence suggests that in addition to visceral fat mass loss, IHCL mainly decrease after six months, whereas ICCL remain unchanged initially but tend to decrease after a longer observation period (>32 months) [230].

\section{Genetics and Drugs}

\subsection{Genetic Background of Ectopic Lipids}

Beyond diet and exercise, genetic disorders—-the so-called lipodystrophy syndromes—can impact on lipid storage within non-adipose tissue. Lipodystrophies are a rare and heterogenous group of disorders, characterized by a complete or a partial lack of white adipose tissue [231]. In general, the amount of fat loss correlates with the associated metabolic abnormalities, including severe insulin resistance (acanthosis nigricans), hypertriglyceridemia, and an increase in ectopic lipid storages, in particular in the liver, which, in turn can lead to inflammation or nonalcoholic steatohepatitis (NASH), fibrosis, and finally hepatocellular carcinoma [232]. It would go beyond the scope of the current review to summarize the understanding of the known lipodystrophy syndromes and their underlying genetic mechanisms (see also [233]). Briefly, mesenchymal stem cells have the capacity to differentiate into adipocytes. They differentiate, firstly, into pre-adipocytes, then into adipocytes (stimulated by insulin, glucocorticoids, IGF-1, and prostaglandines), which in turn differentiate into a mature adipocyte before undergoing apoptosis [234]. Along this pathway several regulatory factors can be mutated, leading to a loss of fat tissue, thereby impairing the lipid handling and storage in the adipose tissue [233]. This results in an excess of lipids in non-adipose tissues. However, whether ectopic lipid accumulation is a sign of disease or a physiological response in patients who have little capacity to store lipids is not clear. Importantly, the major difference between the lipodystrophy syndromes and their associated metabolic abnormality and obesity is the decrease in adipose tissue with low levels of leptin in lipodystrophy, whereas obesity is characterized by an excess of adipose tissue and increased leptin levels [235]. These observations underscore the importance of adipocyte biology in humans.

Lipodystrophy can be considered an extreme version of the obesity-associated metabolic features, including ectopic fat accumulation. It is, therefore, likely that diet and exercise do not influence the flexibility of ectopic lipid stores in a very significant way, but currently no data are available. In contrast, leptin replacement therapy has been shown to result in a significant improvement of the metabolic abnormalities associated with lipodystrophy (including a decrease in IMCL and IHCL) [236-238]. Leptin has, therefore, been approved in Japan and USA for the treatment of diabetes and hypertriglyceridemia in patients with lipodystrophy.

\subsection{Medical Therapy for Ectopic Lipids}

Besides diet and exercise, medical therapy has been investigated in the context of ectopic lipids. The main focus of medical investigations have been IHCL since non-alcoholic steatohepatitis (NASH) is now the most common cause of liver disease and may in the future be the main reason for liver transplantation [239]. Currently there is no approved drug therapy for NASH, but there are 
encouraging results in phase II trials. In the largest randomized-controlled trials in patients with NASH, treatment with pioglitazone, vitamin E [240], and obeticholic acid [241] were associated with improvements in liver histology and/or IHCL relative to placebo. However, long-term safety concerns remain, especially for pioglitazone and vitamin E administration. Recently, the effect of GLP-1 analogues on NASH was tested in two randomized-controlled trials. Using ${ }^{1} \mathrm{H}-\mathrm{MRS}$ the GLP-1 analogue exenatide has been shown to significantly decrease IHCL and epicardial fat, whereas IMCL and intrapancreatic lipids remained unchanged [242]. Similarly, liraglutide therapy, a long-acting GLP-1 analogue, resulted in significant histological improvement of NASH after 48 weeks of therapy [243]. Both compounds were safe and larger phase III studies are awaited.

\section{Conclusions}

Ectopic lipids such as IMCL, IHCL, and ICCL are metabolically active fuel stores. An acute bout of exercise depletes ectopic lipids in "working tissues" (i.e., skeletal muscle and heart muscle) and increases them in the liver. Short-term high-fat dietary intervention leads to repletion of IMCL, whereas the effect of short-term dietary intervention on IHCL is less clear and probably depends on quantitative and qualitative content of the diet. In contrast, a high-fat diet does not seem to affect ICCL. However, we have to acknowledge that there are very limited data available on the effect of a high-fat diet on ICCL.

Short-term starvation results in an increase in IMCL in non-working muscles, in IHCL, and ICCL, whereas long-term caloric restriction tends to decrease IMCL, IHCL, and ICCL. The current evidence suggests that in particular the increased flexibility of IMCL is related to training status and a hallmark of endurance trained athletes, further corroborating the fact that IMCL are metabolically active local fuel stores.

In addition to diet and physical exercise, insulin action plays an important role in regulating the flexibility of ectopic lipids. However, the exact underlying mechanisms are not fully established. Interestingly, preliminary data suggest that the flexibility of ectopic lipids is not only observed in healthy subjects but also in patients with a lack of hormones involved in lipid metabolisms such as growth hormone deficiency and type 1 diabetes mellitus.

Congenital lipodystrophies are rare and heterogeneous genetic disorders characterized by a complete or partial lack of subcutaneous tissue resulting in an overflow of fat metabolites in ectopic tissues. Metabolically, they can be considered an extreme version of the obesity-associated metabolic features. In contrast to obesity-related metabolic abnormalities, lipodystrophy is associated with a lack of leptin and leptin replacement therapy has been shown to improve insulin resistance and hypertriglyceridemia in patients with lipodystrophy. The main focus of medical investigations has been IHCL. Encouraging results of randomized controlled phase II trial have been reported with pioglitazone, vitamin E, obeticholic acid, and GLP-1 agonists. However, so far there is no drug approved for the therapy of steatohepatitis.

The available evidence suggests that a complex interplay including quantitative and qualitative diet, fat availability (fat mass, FFAs), insulin action, genetic background [244], and physical exercise are important factors that influence ectopic lipids (Figure 4). Furthermore, the time frame of the intervention on these parameters (short-term vs. long-term) appears to be critical. Consequently, standardization of physical activity and diet is mandatory when assessing ectopic lipids in predefined clinical situations. 
diet

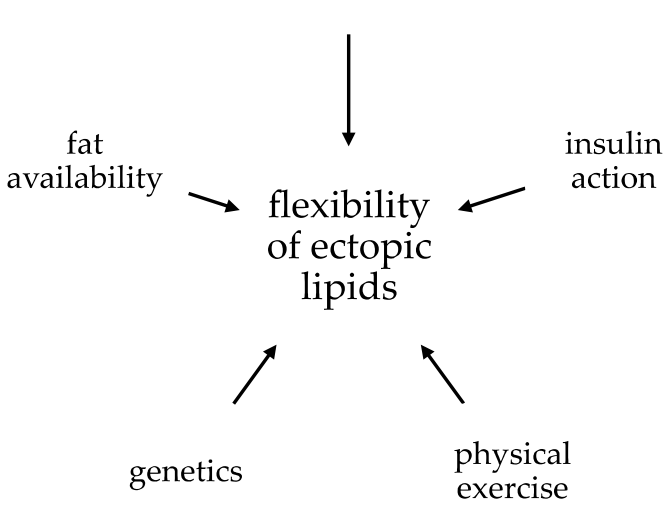

Figure 4. Factors influencing lipids: See text for details.

Acknowledgments: This work was supported by Swiss National Science Foundation grants No. 320030_130331, 320030_124873 to Emanuel Christ, and No. 310030_149779 and 31003A_132935 to Chris Boesch.

Conflicts of Interest: The authors declare no conflict of interest with regard to this manuscript.

\section{References}

1. Field, A.E.; Coakley, E.H.; Must, A.; Spadano, J.L.; Laird, N.; Dietz, W.H.; Rimm, E.; Colditz, G.A. Impact of overweight on the risk of developing common chronic diseases during a 10-year period. Arch. Intern. Med. 2001, 161, 1581-1586. [CrossRef] [PubMed]

2. Wilson, P.W.; D'Agostino, R.B.; Sullivan, L.; Parise, H.; Kannel, W.B. Overweight and obesity as determinants of cardiovascular risk: The Framingham experience. Arch. Intern. Med. 2002, 162, 1867-1872. [CrossRef] [PubMed]

3. Sheth, S.G.; Gordon, F.D.; Chopra, S. Nonalcoholic steatohepatitis. Ann. Intern. Med. 1997, 126, 137-145. [CrossRef] [PubMed]

4. Wanless, I.R.; Lentz, J.S. Fatty liver hepatitis (steatohepatitis) and obesity: An autopsy study with analysis of risk factors. Hepatology 1990, 12, 1106-1110. [CrossRef] [PubMed]

5. Eckel, R.H. Obesity and heart disease: A statement for healthcare professionals from the Nutrition Committee, American Heart Association. Circulation 1997, 96, 3248-3250. [CrossRef] [PubMed]

6. Engeland, A.; Bjorge, T.; Selmer, R.M.; Tverdal, A. Height and body mass index in relation to total mortality. Epidemiology 2003, 14, 293-299. [CrossRef] [PubMed]

7. Hubert, H.B.; Feinleib, M.; McNamara, P.M.; Castelli, W.P. Obesity as an independent risk factor for cardiovascular disease: A 26-year follow-up of participants in the Framingham Heart Study. Circulation 1983, 67, 968-977. [CrossRef] [PubMed]

8. Targher, G.; Byrne, C.D.; Lonardo, A.; Zoppini, G.; Barbui, C. Nonalcoholic Fatty Liver Disease and Risk of Incident Cardiovascular Disease: A Meta-Analysis of Observational Studies. J. Hepatol. 2016, 65, 589-600. [CrossRef] [PubMed]

9. Kuk, J.L.; Katzmarzyk, P.T.; Nichaman, M.Z.; Church, T.S.; Blair, S.N.; Ross, R. Visceral fat is an independent predictor of all-cause mortality in men. Obesity 2006, 14, 336-341. [CrossRef] [PubMed]

10. Nicklas, B.J.; Penninx, B.W.; Cesari, M.; Kritchevsky, S.B.; Newman, A.B.; Kanaya, A.M.; Pahor, M.; Jingzhong, D.; Harris, T.B. Association of visceral adipose tissue with incident myocardial infarction in older men and women: The Health, Aging and Body Composition Study. Am. J. Epidemiol. 2004, 160, 741-749. [CrossRef] [PubMed]

11. Britton, K.A.; Massaro, J.M.; Murabito, J.M.; Kreger, B.E.; Hoffmann, U.; Fox, C.S. Body fat distribution, incident cardiovascular disease, cancer, and all-cause mortality. J. Am. Coll. Cardiol. 2013, 62, 921-925. [CrossRef] [PubMed]

12. Miyazaki, Y.; Glass, L.; Triplitt, C.; Wajcberg, E.; Mandarino, L.J.; DeFronzo, R.A. Abdominal fat distribution and peripheral and hepatic insulin resistance in type 2 diabetes mellitus. Am. J. Physiol. Endocrinol. Metab. 2002, 283, E1135-E1143. [CrossRef] [PubMed] 
13. Cefalu, W.T.; Wang, Z.Q.; Werbel, S.; Bell-Farrow, A.; Crouse, J.R., 3rd; Hinson, W.H.; Terry, J.G.; Anderson, R. Contribution of visceral fat mass to the insulin resistance of aging. Metab. Clin. Exp. 1995, 44, 954-959. [CrossRef]

14. Boyko, E.J.; Fujimoto, W.Y.; Leonetti, D.L.; Newell-Morris, L. Visceral adiposity and risk of type 2 diabetes: A prospective study among Japanese Americans. Diabetes Care 2000, 23, 465-471. [CrossRef] [PubMed]

15. Chechi, K.; Richard, D. Thermogenic potential and physiological relevance of human epicardial adipose tissue. Int. J. Obes. Suppl. 2015, 5, S28-S34. [CrossRef] [PubMed]

16. Szendroedi, J.; Roden, M. Ectopic lipids and organ function. Curr. Opin. Lipidol. 2009, 20, 50-56. [CrossRef] [PubMed]

17. Van Herpen, N.A.; Schrauwen-Hinderling, V.B. Lipid accumulation in non-adipose tissue and lipotoxicity. Physiol. Behav. 2008, 94, 231-241. [CrossRef] [PubMed]

18. Taira, S.; Shimabukuro, M.; Higa, M.; Yabiku, K.; Kozuka, C.; Ueda, R.; Sunagawa, S.; Ohshiro, Y.; Doi, M.; Nanba, T.; et al. Lipid deposition in various sites of the skeletal muscles and liver exhibits a positive correlation with visceral fat accumulation in middle-aged Japanese men with metabolic syndrome. Intern. Med. 2013, 52, 1561-1571. [CrossRef] [PubMed]

19. Snel, M.; Jonker, J.T.; Schoones, J.; Lamb, H.; de Roos, A.; Pijl, H.; Smit, J.W.; Meinders, A.E.; Jazet, I.M. Ectopic fat and insulin resistance: Pathophysiology and effect of diet and lifestyle interventions. Int. J. Endocrinol. 2012, 2012, 983814. [CrossRef] [PubMed]

20. Kotronen, A.; Westerbacka, J.; Bergholm, R.; Pietiläinen, K.H.; Yki-Järvinen, H. Liver fat in the metabolic syndrome. J. Clin. Endocrinol. Metab. 2007, 92, 3490-3497. [CrossRef] [PubMed]

21. Phillips, D.I.; Caddy, S.; Ilic, V.; Fielding, B.A.; Frayn, K.N.; Borthwick, A.C.; Taylor, R. Intramuscular triglyceride and muscle insulin sensitivity: Evidence for a relationship in nondiabetic subjects. Metab. Clin. Exp. 1996, 45, 947-950. [CrossRef]

22. Banerji, M.A.; Buckley, M.C.; Chaiken, R.L.; Gordon, D.; Lebovitz, H.E.; Kral, J.G. Liver fat, serum triglycerides and visceral adipose tissue in insulin-sensitive and insulin-resistant black men with NIDDM. Int. J. Obes. Relat. Metab. Disord. 1995, 19, 846-850. [PubMed]

23. Browning, J.D.; Baxter, J.; Satapati, S.; Burgess, S.C. The effect of short-term fasting on liver and skeletal muscle lipid, glucose, and energy metabolism in healthy women and men. J. Lipid Res. 2012, 53, 577-586. [CrossRef] [PubMed]

24. Green, J.G.; Johnson, N.A.; Sachinwalla, T.; Cunningham, C.W.; Thompson, M.W.; Stannard, S.R. Low-carbohydrate diet does not affect intramyocellular lipid concentration or insulin sensitivity in lean, physically fit men when protein intake is elevated. Metab. Clin. Exp. 2010, 59, 1633-1641. [CrossRef] [PubMed]

25. Stannard, S.R.; Thompson, M.W.; Fairbairn, K.; Huard, B.; Sachinwalla, T.; Thompson, C.H. Fasting for 72 h increases intramyocellular lipid content in nondiabetic, physically fit men. Am. J. Physiol. Endocrinol. Metab. 2002, 283, E1185-E1191. [CrossRef] [PubMed]

26. Wietek, B.M.; Machann, J.; Mader, I.; Thamer, C.; Häring, H.U.; Claussen, C.D.; Stumvoll, M.; Schick, F. Muscle type dependent increase in intramyocellular lipids during prolonged fasting of human subjects: A proton MRS study. Horm. Metab. Res. 2004, 36, 639-644. [CrossRef] [PubMed]

27. Machann, J.; Etzel, M.; Thamer, C.; Haring, H.U.; Claussen, C.D.; Fritsche, A.; Schick, F. Morning to evening changes of intramyocellular lipid content in dependence on nutrition and physical activity during one single day: A volume selective 1H-MRS study. MAGMA 2011, 24, 29-33. [CrossRef] [PubMed]

28. Bachmann, O.P.; Dahl, D.B.; Brechtel, K.; Machann, J.; Haap, M.; Maier, T.; Loviscach, M.; Stumvoll, M.; Claussen, C.D.; Schick, F.; et al. Effects of intravenous and dietary lipid challenge on intramyocellular lipid content and the relation with insulin sensitivity in humans. Diabetes 2001, 50, 2579-2584. [CrossRef] [PubMed]

29. Sakurai, Y.; Tamura, Y.; Takeno, K.; Kumashiro, N.; Sato, F.; Kakehi, S.; Ikeda, S.; Ogura, Y.; Saga, N.; Naito, H.; et al. Determinants of intramyocellular lipid accumulation after dietary fat loading in non-obese men. J. Diabetes Investig. 2011, 2, 310-317. [CrossRef] [PubMed]

30. Zderic, T.W.; Davidson, C.J.; Schenk, S.; Byerley, L.O.; Coyle, E.F. High-fat diet elevates resting intramuscular triglyceride concentration and whole body lipolysis during exercise. Am. J. Physiol. Endocrinol. Metab. 2004, 286, E217-E225. [CrossRef] [PubMed] 
31. Larson-Meyer, D.E.; Borkhsenious, O.N.; Gullett, J.C.; Russell, R.D.; Devries, M.C.; Smith, S.R.; Ravussin, E. Effect of dietary fat on serum and intramyocellular lipids and running performance. Med. Sci. Sports Exerc. 2008, 40, 892-902. [CrossRef] [PubMed]

32. Van Proeyen, K.; Szlufcik, K.; Nielens, H.; Deldicque, L.; van Dyck, R.; Ramaekers, M.; Hespel, P. High-fat diet overrules the effects of training on fiber-specific intramyocellular lipid utilization during exercise. J. Appl. Physiol. 2011, 111, 108-116. [CrossRef] [PubMed]

33. Lindeboom, L.; Nabuurs, C.I.; Hesselink, M.K.; Wildberger, J.E.; Schrauwen, P.; Schrauwen-Hinderling, V.B. Proton magnetic resonance spectroscopy reveals increased hepatic lipid content after a single high-fat meal with no additional modulation by added protein. Am. J. Clin. Nutr. 2015, 101, 65-71. [CrossRef] [PubMed]

34. Van der Meer, R.W.; Hammer, S.; Smit, J.W.; Frölich, M.; Bax, J.J.; Diamant, M.; Rijzewijk, L.J.; de Roos, A.; Romijn, J.A.; Lamb, H.J. Short-term caloric restriction induces accumulation of myocardial triglycerides and decreases left ventricular diastolic function in healthy subjects. Diabetes 2007, 56, 2849-2853. [CrossRef] [PubMed]

35. Van der Meer, R.W.; Hammer, S.; Lamb, H.J.; Frölich, M.; Diamant, M.; Rijzewijk, L.J.; de Roos, A.; Romijn, J.A.; Smit, J.W. Effects of short-term high-fat, high-energy diet on hepatic and myocardial triglyceride content in healthy men. J. Clin. Endocrinol. Metab. 2008, 93, 2702-2708. [CrossRef] [PubMed]

36. Bortolotti, M.; Kreis, R.; Debard, C.; Cariou, B.; Faeh, D.; Chetiveaux, M.; Ith, M.; Vermathen, P.; Stefanoni, N.; Lê, K.A.; et al. High protein intake reduces intrahepatocellular lipid deposition in humans. Am. J. Clin. Nutr. 2009, 90, 1002-1010. [CrossRef] [PubMed]

37. Zehnder, M.; Christ, E.R.; Ith, M.; Acheson, K.J.; Pouteau, E.; Kreis, R.; Trepp, R.; Diem, P.; Boesch, C.; Décombaz, J. Intramyocellular lipid stores increase markedly in athletes after 1.5 days lipid supplementation and are utilized during exercise in proportion to their content. Eur. J. Appl. Physiol. 2006, 98, 341-354. [CrossRef] [PubMed]

38. Larson-Meyer, D.E.; Newcomer, B.R.; Hunter, G.R. Influence of endurance running and recovery diet on intramyocellular lipid content in women: A 1H NMR study. Am. J. Physiol. Endocrinol. Metab. 2002, 282, E95-E106. [PubMed]

39. Décombaz, J.; Schmitt, B.; Ith, M.; Decarli, B.; Diem, P.; Kreis, R.; Hoppeler, H.; Boesch, C. Postexercise fat intake repletes intramyocellular lipids but no faster in trained than in sedentary subjects. Am. J. Physiol. Regul. Integr. Comp. Physiol. 2001, 281, R760-R769. [PubMed]

40. Brehm, A.; Krššák, M.; Schmid, A.I.; Nowotny, P.; Waldhäusl, W.; Roden, M. Acute elevation of plasma lipids does not affect ATP synthesis in human skeletal muscle. Am. J. Physiol. Endocrinol. Metab. 2010, 299, E33-E38. [CrossRef] [PubMed]

41. Johnson, N.A.; Stannard, S.R.; Rowlands, D.S.; Chapman, P.G.; Thompson, C.H.; O'Connor, H.; Sachinwalla, T.; Thompson, M.W. Effect of short-term starvation versus high-fat diet on intramyocellular triglyceride accumulation and insulin resistance in physically fit men. Exp. Physiol. 2006, 91, 693-703. [CrossRef] [PubMed]

42. Décombaz, J.; Fleith, M.; Hoppeler, H.; Kreis, R.; Boesch, C. Effect of diet on the replenishment of intramyocellular lipids after exercise. Eur. J. Nutr. 2000, 39, 244-247. [CrossRef]

43. Bucher, J.; Krüsi, M.; Zueger, T.; Ith, M.; Stettler, C.; Diem, P.; Boesch, C.; Kreis, R.; Christ, E. The effect of a single $2 \mathrm{~h}$ bout of aerobic exercise on ectopic lipids in skeletal muscle, liver and the myocardium. Diabetologia 2014, 57, 1001-1005. [CrossRef] [PubMed]

44. Egger, A.; Kreis, R.; Allemann, S.; Stettler, C.; Diem, P.; Buehler, T.; Boesch, C.; Christ, E.R. The effect of aerobic exercise on intrahepatocellular and intramyocellular lipids in healthy subjects. PLoS ONE 2013, 8, e70865. [CrossRef] [PubMed]

45. White, L.J.; Ferguson, M.A.; McCoy, S.C.; Kim, H. Intramyocellular lipid changes in men and women during aerobic exercise: A ${ }^{1} \mathrm{H}$-magnetic resonance spectroscopy study. J. Clin. Endocrinol. Metab. 2003, 88, 5638-5643. [CrossRef] [PubMed]

46. White, L.J.; Robergs, R.A.; Sibbitt, W.L., Jr.; Ferguson, M.A.; McCoy, S.; Brooks, W.M. Effects of intermittent cycle exercise on intramyocellular lipid use and recovery. Lipids 2003, 38, 9-13. [CrossRef] [PubMed]

47. Vermathen, P.; Saillen, P.; Boss, A.; Zehnder, M.; Boesch, C. Skeletal muscle ${ }^{1}$ H-MRSI before and after prolonged exercise. I. muscle specific depletion of intramyocellular lipids. Magn. Reson. Med. 2012, 68, 1357-1367. [CrossRef] [PubMed] 
48. De Bock, K.; Dresselaers, T.; Kiens, B.; Richter, E.A.; Van Hecke, P.; Hespel, P. Evaluation of intramyocellular lipid breakdown during exercise by biochemical assay, NMR spectroscopy, and Oil Red O staining. Am. J. Physiol. Endocrinol. Metab. 2007, 293, E428-E434. [CrossRef] [PubMed]

49. Zehnder, M.; Ith, M.; Kreis, R.; Saris, W.; Boutellier, U.; Boesch, C. Gender-specific usage of intramyocellular lipids and glycogen during exercise. Med. Sci. Sports Exerc. 2005, 37, 1517-1524. [CrossRef] [PubMed]

50. Schrauwen-Hinderling, V.B.; van Loon, L.J.; Koopman, R.; Nicolay, K.; Saris, W.H.; Kooi, M.E. Intramyocellular lipid content is increased after exercise in nonexercising human skeletal muscle. J. Appl. Physiol. 2003, 95, 2328-2332. [CrossRef] [PubMed]

51. Van Loon, L.J.; Schrauwen-Hinderling, V.B.; Koopman, R.; Wagenmakers, A.J.; Hesselink, M.K.; Schaart, G.; Kooi, M.E.; Saris, W.H. Influence of prolonged endurance cycling and recovery diet on intramuscular triglyceride content in trained males. Am. J. Physiol. Endocrinol. Metab. 2003, 285, E804-E811. [CrossRef] [PubMed]

52. Johnson, N.A.; Stannard, S.R.; Mehalski, K.; Trenell, M.I.; Sachinwalla, T.; Thompson, C.H.; Thompson, M.W. Intramyocellular triacylglycerol in prolonged cycling with high- and low-carbohydrate availability. J. Appl. Physiol. 2003, 94, 1365-1372. [CrossRef] [PubMed]

53. Brechtel, K.; Niess, A.M.; Machann, J.; Rett, K.; Schick, F.; Claussen, C.D.; Dickhuth, H.H.; Haering, H.U.; Jacob, S. Utilisation of intramyocellular lipids (IMCLs) during exercise as assessed by proton magnetic resonance spectroscopy (1H-MRS). Horm. Metab. Res. 2001, 33, 63-66. [CrossRef] [PubMed]

54. Krssak, M.; Petersen, K.F.; Bergeron, R.; Price, T.; Laurent, D.; Rothman, D.L.; Roden, M.; Shulman, G.I. Intramuscular glycogen and intramyocellular lipid utilization during prolonged exercise and recovery in man: $\mathrm{A}^{13} \mathrm{C}$ and ${ }^{1} \mathrm{H}$ nuclear magnetic resonance spectroscopy study. J. Clin. Endocrinol. Metab. 2000, 85, 748-754. [CrossRef] [PubMed]

55. Rico-Sanz, J.; Moosavi, M.; Thomas, E.L.; McCarthy, J.; Coutts, G.A.; Saeed, N.; Bell, J.D. In vivo evaluation of the effects of continuous exercise on skeletal muscle triglycerides in trained humans. Lipids 2000, 35, 1313-1318. [CrossRef] [PubMed]

56. Ith, M.; Huber, P.M.; Egger, A.; Schmid, J.P.; Kreis, R.; Christ, E.; Boesch, C. Standardized protocol for a depletion of intramyocellular lipids (IMCL). NMR Biomed. 2010, 23, 532-538. [CrossRef] [PubMed]

57. Boesch, C.; Slotboom, J.; Hoppeler, H.; Kreis, R. In vivo determination of intra-myocellular lipids in human muscle by means of localized 1H-MR-spectroscopy. Magn. Reson. Med. 1997, 37, 484-493. [CrossRef] [PubMed]

58. De Bock, K.; Richter, E.A.; Russell, A.P.; Eijnde, B.O.; Derave, W.; Ramaekers, M.; Koninckx, E.; Léger, B.; Verhaeghe, J.; Hespel, P. Exercise in the fasted state facilitates fibre type-specific intramyocellular lipid breakdown and stimulates glycogen resynthesis in humans. J. Physiol. 2005, 564, 649-660. [CrossRef] [PubMed]

59. Hurley, B.F.; Nemeth, P.M.; Martin, W.H., 3rd; Hagberg, J.M.; Dalsky, G.P.; Holloszy, J.O. Muscle triglyceride utilization during exercise: Effect of training. J. Appl. Physiol. 1986, 60, 562-567. [PubMed]

60. van Loon, L.J.; Koopman, R.; Stegen, J.H.; Wagenmakers, A.J.; Keizer, H.A.; Saris, W.H. Intramyocellular lipids form an important substrate source during moderate intensity exercise in endurance-trained males in a fasted state. J. Physiol. 2003, 553, 611-625. [CrossRef] [PubMed]

61. Shepherd, S.O.; Cocks, M.; Tipton, K.D.; Ranasinghe, A.M.; Barker, T.A.; Burniston, J.G.; Wagenmakers, A.J.; Shaw, C.S. Preferential utilization of perilipin 2-associated intramuscular triglycerides during $1 \mathrm{~h}$ of moderate-intensity endurance-type exercise. Exp. Physiol. 2012, 97, 970-980. [CrossRef] [PubMed]

62. Shepherd, S.O.; Cocks, M.; Tipton, K.D.; Ranasinghe, A.M.; Barker, T.A.; Burniston, J.G.; Wagenmakers, A.J.; Shaw, C.S. Sprint interval and traditional endurance training increase net intramuscular triglyceride breakdown and expression of perilipin 2 and 5. J. Physiol. 2013, 591, 657-675. [CrossRef] [PubMed]

63. Stellingwerff, T.; Boon, H.; Gijsen, A.P.; Stegen, J.H.; Kuipers, H.; van Loon, L.J. Carbohydrate supplementation during prolonged cycling exercise spares muscle glycogen but does not affect intramyocellular lipid use. Pflug. Arch. Eur. J. Physiol. 2007, 454, 635-647. [CrossRef] [PubMed]

64. Watt, M.J.; Heigenhauser, G.J.; Dyck, D.J.; Spriet, L.L. Intramuscular triacylglycerol, glycogen and acetyl group metabolism during $4 \mathrm{~h}$ of moderate exercise in man. J. Physiol. 2002, 541, 969-978. [CrossRef] [PubMed]

65. Jenni, S.; Oetliker, C.; Allemann, S.; Ith, M.; Tappy, L.; Wuerth, S.; Egger, A.; Boesch, C.; Schneiter, P.; Diem, P.; et al. Fuel metabolism during exercise in euglycaemia and hyperglycaemia in patients with type 1 diabetes mellitus-A prospective single-blinded randomised crossover trial. Diabetologia 2008, 51, 1457-1465. [CrossRef] [PubMed] 
66. Trepp, R.; Flück, M.; Stettler, C.; Boesch, C.; Ith, M.; Kreis, R.; Hoppeler, H.; Howald, H.; Schmid, J.P.; Diem, P.; et al. Effect of GH on human skeletal muscle lipid metabolism in GH deficiency. Am. J. Physiol. Endocrinol. Metab. 2008, 294, E1127-E1134. [CrossRef] [PubMed]

67. Christ, E.R.; Egger, A.; Allemann, S.; Buehler, T.; Kreis, R.; Boesch, C. Effects of aerobic exercise on ectopic lipids in patients with growth hormone deficiency before and after growth hormone replacement therapy. Sci. Rep. 2016, 6, 19310. [CrossRef] [PubMed]

68. Rico-Sanz, J.; Hajnal, J.V.; Thomas, E.L.; Mierisová, S.; Ala-Korpela, M.; Bell, J.D. Intracellular and extracellular skeletal muscle triglyceride metabolism during alternating intensity exercise in humans. J. Physiol. 1998, 510, 615-622. [CrossRef] [PubMed]

69. Bilet, L.; Brouwers, B.; van Ewijk, P.A.; Hesselink, M.K.; Kooi, M.E.; Schrauwen, P.; Schrauwen-Hinderling, V.B. Acute exercise does not decrease liver fat in men with overweight or NAFLD. Sci. Rep. 2015, 5. [CrossRef] [PubMed]

70. Johnson, N.A.; van Overbeek, D.; Chapman, P.G.; Thompson, M.W.; Sachinwalla, T.; George, J. Effect of prolonged exercise and pre-exercise dietary manipulation on hepatic triglycerides in trained men. Eur. J. Appl. Physiol. 2012, 112, 1817-1825. [CrossRef] [PubMed]

71. Shaw, C.S.; Shepherd, S.O.; Wagenmakers, A.J.; Hansen, D.; Dendale, P.; van Loon, L.J. Prolonged exercise training increases intramuscular lipid content and perilipin 2 expression in type I muscle fibers of patients with type 2 diabetes. Am. J. Physiol. Endocrinol. Metab. 2012, 303, E1158-E1165. [CrossRef] [PubMed]

72. Nielsen, J.; Mogensen, M.; Vind, B.F.; Sahlin, K.; Højlund, K.; Schrøder, H.D.; Ortenblad, N. Increased subsarcolemmal lipids in type 2 diabetes: Effect of training on localization of lipids, mitochondria, and glycogen in sedentary human skeletal muscle. Am. J. Physiol. Endocrinol. Metab. 2010, 298, E706-E713. [CrossRef] [PubMed]

73. Jonker, J.T.; de Mol, P.; de Vries, S.T.; Widya, R.L.; Hammer, S.; van Schinkel, L.D.; van der Meer, R.W.; Gans, R.O.; Webb, A.G.; Kan, H.E.; et al. Exercise and type 2 diabetes mellitus: Changes in tissue-specific fat distribution and cardiac function. Radiology 2013, 269, 434-442. [CrossRef] [PubMed]

74. Bruce, C.R.; Kriketos, A.D.; Cooney, G.J.; Hawley, J.A. Disassociation of muscle triglyceride content and insulin sensitivity after exercise training in patients with Type 2 diabetes. Diabetologia 2004, 47, 23-30. [CrossRef] [PubMed]

75. Kim, H.J.; Lee, J.S.; Kim, C.K. Effect of exercise training on muscle glucose transporter 4 protein and intramuscular lipid content in elderly men with impaired glucose tolerance. Eur. J. Appl. Physiol. 2004, 93, 353-358. [CrossRef] [PubMed]

76. Phillips, S.M.; Green, H.J.; Tarnopolsky, M.A.; Heigenhauser, G.J.; Grant, S.M. Progressive effect of endurance training on metabolic adaptations in working skeletal muscle. Am. J. Physiol. 1996, 270, E265-E272. [PubMed]

77. Stellingwerff, T.; Boon, H.; Jonkers, R.A.; Senden, J.M.; Spriet, L.L.; Koopman, R.; van Loon, L.J. Significant intramyocellular lipid use during prolonged cycling in endurance-trained males as assessed by three different methodologies. Am. J. Physiol. Endocrinol. Metab. 2007, 292, E1715-E1723. [CrossRef] [PubMed]

78. Koopman, R.; Manders, R.J.; Jonkers, R.A.; Hul, G.B.; Kuipers, H.; van Loon, L.J. Intramyocellular lipid and glycogen content are reduced following resistance exercise in untrained healthy males. Eur. J. Appl. Physiol. 2006, 96, 525-534. [CrossRef] [PubMed]

79. Sacchetti, M.; Saltin, B.; Osada, T.; van Hall, G. Intramuscular fatty acid metabolism in contracting and non-contracting human skeletal muscle. J. Physiol. 2002, 540, 387-395. [CrossRef] [PubMed]

80. Folch, J.; Lees, M.; Sloane-Stanley, G.H. A simple method for the isolation and purification of total lipides from animal tissues. J. Biol. Chem. 1957, 226, 497-509. [PubMed]

81. Wendling, P.S.; Peters, S.J.; Heigenhauser, G.J.; Spriet, L.L. Variability of triacylglycerol content in human skeletal muscle biopsy samples. J. Appl. Physiol. 1996, 81, 1150-1155. [PubMed]

82. Starling, R.D.; Trappe, T.A.; Parcell, A.C.; Kerr, C.G.; Fink, W.J.; Costill, D.L. Effects of diet on muscle triglyceride and endurance performance. J. Appl. Physiol. 1997, 82, 1185-1189. [PubMed]

83. Kiens, B.; Richter, E.A. Utilization of skeletal muscle triacylglycerol during postexercise recovery in humans. Am. J. Physiol. 1998, 275, E332-E337. [PubMed]

84. Essén, B.; Hagenfeldt, L.; Kaijser, L. Utilization of blood-borne and intramuscular substrates during continuous and intermittent exercise in man. J. Physiol. 1977, 265, 489-506. [CrossRef] [PubMed]

85. Kiens, B.; Essen-Gustavsson, B.; Christensen, N.J.; Saltin, B. Skeletal muscle substrate utilization during submaximal exercise in man: Effect of endurance training. J. Physiol. 1993, 469, 459-478. [CrossRef] [PubMed] 
86. Howald, H.; Boesch, C.; Kreis, R.; Matter, S.; Billeter, R.; Essen-Gustavsson, B.; Hoppeler, H. Content of intramyocellular lipids derived by electron microscopy, biochemical assays, and ${ }^{1} \mathrm{H}-\mathrm{MR}$ spectroscopy. J. Appl. Physiol. 2002, 92, 2264-2272. [CrossRef] [PubMed]

87. Goodpaster, B.H.; Theriault, R.; Watkins, S.C.; Kelley, D.E. Intramuscular lipid content is increased in obesity and decreased by weight loss. Metab. Clin. Exp. 2000, 49, 467-472. [CrossRef]

88. Schick, F.; Eismann, B.; Jung, W.I.; Bongers, H.; Bunse, M.; Lutz, O. Comparison of localized proton NMR signals of skeletal muscle and fat tissue in vivo: Two lipid compartments in muscle tissue. Magn. Reson. Med. 1993, 29, 158-167. [CrossRef] [PubMed]

89. Boesch, C.; Décombaz, J.; Slotboom, J.; Kreis, R. Observation of intramyocellular lipids by means of $1 \mathrm{H}$ magnetic resonance spectroscopy. Proc. Nutr. Soc. 1999, 58, 841-850. [CrossRef] [PubMed]

90. Boesch, C.; Machann, J.; Vermathen, P.; Schick, F. Role of proton MR for the study of muscle lipid metabolism. NMR Biomed. 2006, 19, 968-988. [CrossRef] [PubMed]

91. Szczepaniak, L.S.; Babcock, E.E.; Schick, F.; Dobbins, R.L.; Garg, A.; Burns, D.K.; McGarry, J.D.; Stein, D.T. Measurement of intracellular triglyceride stores by $\mathrm{H}$ spectroscopy: Validation in vivo. Am. J. Physiol. 1999, 276, E977-E989. [PubMed]

92. Ahmed, A.; Wong, R.J.; Harrison, S.A. Nonalcoholic Fatty Liver Disease Review: Diagnosis, Treatment, and Outcomes. Clin. Gastroenterol. Hepatol. 2015, 13, 2062-2070. [CrossRef] [PubMed]

93. Longo, R.; Ricci, C.; Masutti, F.; Vidimari, R.; Crocé, L.S.; Bercich, L.; Tiribelli, C.; Dalla Palma, L. Fatty infiltration of the liver. Quantification by $1 \mathrm{H}$ localized magnetic resonance spectroscopy and comparison with computed tomography. Investig. Radiol. 1993, 28, 297-302. [CrossRef]

94. Thomsen, C.; Becker, U.; Winkler, K.; Christoffersen, P.; Jensen, M.; Henriksen, O. Quantification of liver fat using magnetic resonance spectroscopy. Magn. Reson. Imaging 1994, 12, 487-495. [CrossRef]

95. Parente, D.B.; Rodrigues, R.S.; Paiva, F.F.; Oliveira Neto, J.A.; Machado-Silva, L.; Lanzoni, V.; Campos, C.F.; Eiras-Araujo, A.L.; do Brasil, P.E.; Garteiser, P.; et al. Is MR spectroscopy really the best MR-based method for the evaluation of fatty liver in diabetic patients in clinical practice? PLoS ONE 2014, 9, e112574. [CrossRef] [PubMed]

96. Bannas, P.; Kramer, H.; Hernando, D.; Agni, R.; Cunningham, A.M.; Mandal, R.; Motosugi, U.; Sharma, S.D.; Munoz del Rio, A.; Fernandez, L.; et al. Quantitative MR Imaging of Hepatic Steatosis: Validation in Ex Vivo Human Livers. Hepatology 2015, 62, 1444-1455. [CrossRef] [PubMed]

97. Cowin, G.J.; Jonsson, J.R.; Bauer, J.D.; Ash, S.; Ali, A.; Osland, E.J.; Purdie, D.M.; Clouston, A.D.; Powell, E.E.; Galloway, G.J. Magnetic resonance imaging and spectroscopy for monitoring liver steatosis. J. Magn. Reson. Imaging 2008, 28, 937-945. [CrossRef] [PubMed]

98. McPherson, S.; Jonsson, J.R.; Cowin, G.J.; O’Rourke, P.; Clouston, A.D.; Volp, A.; Horsfall, L.; Jothimani, D.; Fawcett, J.; Galloway, G.J.; et al. Magnetic resonance imaging and spectroscopy accurately estimate the severity of steatosis provided the stage of fibrosis is considered. J. Hepatol. 2009, 51, 389-397. [CrossRef] [PubMed]

99. Szczepaniak, L.S.; Nurenberg, P.; Leonard, D.; Browning, J.D.; Reingold, J.S.; Grundy, S.; Hobbs, H.H.; Dobbins, R.L. Magnetic resonance spectroscopy to measure hepatic triglyceride content: Prevalence of hepatic steatosis in the general population. Am. J. Physiol. Endocrinol. Metab. 2005, 288, E462-E468. [CrossRef] [PubMed]

100. Hu, H.H.; Kan, H.E. Quantitative proton MR techniques for measuring fat. NMR Biomed. 2013, 26, 1609-1629. [CrossRef] [PubMed]

101. Ith, M.; Stettler, C.; Xu, J.; Boesch, C.; Kreis, R. Cardiac lipid levels show diurnal changes and long-term variations in healthy human subjects. NMR Biomed. 2014, 27, 1285-1292. [CrossRef] [PubMed]

102. Reingold, J.S.; McGavock, J.M.; Kaka, S.; Tillery, T.; Victor, R.G.; Szczepaniak, L.S. Determination of triglyceride in the human myocardium by magnetic resonance spectroscopy: Reproducibility and sensitivity of the method. Am. J. Physiol. Endocrinol. Metab. 2005, 289, E935-E939. [CrossRef] [PubMed]

103. Faller, K.M.; Lygate, C.A.; Neubauer, S.; Schneider, J.E. ${ }^{1}$ H-MR spectroscopy for analysis of cardiac lipid and creatine metabolism. Heart Fail. Rev. 2013, 18, 657-668. [CrossRef] [PubMed]

104. O'Connor, R.D.; Xu, J.; Ewald, G.A.; Ackerman, J.J.; Peterson, L.R.; Gropler, R.J.; Bashir, A. Intramyocardial triglyceride quantification by magnetic resonance spectroscopy: In vivo and ex vivo correlation in human subjects. Magn. Reson. Med. 2011, 65, 1234-1238. [CrossRef] [PubMed] 
105. Van der Meer, R.W.; Doornbos, J.; Kozerke, S.; Schär, M.; Bax, J.J.; Hammer, S.; Smit, J.W.; Romijn, J.A.; Diamant, M.; Rijzewijk, L.J.; et al. Metabolic imaging of myocardial triglyceride content: Reproducibility of 1H-MR spectroscopy with respiratory navigator gating in volunteers. Radiology 2007, 245, 251-257. [CrossRef] [PubMed]

106. Vermathen, P.; Kreis, R.; Boesch, C. Distribution of intramyocellular lipids in human calf muscles as determined by MR spectroscopic imaging. Magn. Reson. Med. 2004, 51, 253-262. [CrossRef] [PubMed]

107. Reeder, S.B.; Cruite, I.; Hamilton, G.; Sirlin, C.B. Quantitative assessment of liver fat with magnetic resonance imaging and spectroscopy. J. Magn. Reson. Imaging 2011, 34, 729-749. [CrossRef] [PubMed]

108. Weiss, K.; Martini, N.; Boesiger, P.; Kozerke, S. Metabolic MR imaging of regional triglyceride and creatine content in the human heart. Magn. Reson. Med. 2012, 68, 1696-1704. [CrossRef] [PubMed]

109. Jansson, E.; Kaijser, L. Substrate utilization and enzymes in skeletal muscle of extremely endurance-trained men. J. Appl. Physiol. 1987, 62, 999-1005. [PubMed]

110. Jansson, E.; Kaijser, L. Effect of diet on the utilization of blood-borne and intramuscular substrates during exercise in man. Acta Physiol. Scand. 1982, 115, 19-30. [CrossRef] [PubMed]

111. Perreault, L.; Bergman, B.C.; Hunerdosse, D.M.; Playdon, M.C.; Eckel, R.H. Inflexibility in intramuscular triglyceride fractional synthesis distinguishes prediabetes from obesity in humans. Obesity 2010, 18, 1524-1531. [CrossRef] [PubMed]

112. Lundsgaard, A.M.; Kiens, B. Gender differences in skeletal muscle substrate metabolism-Molecular mechanisms and insulin sensitivity. Front. Endocrinol. 2014, 5. [CrossRef] [PubMed]

113. Schrauwen-Hinderling, V.B.; Schrauwen, P.; Hesselink, M.K.; van Engelshoven, J.M.; Nicolay, K.; Saris, W.H.; Kessels, A.G.; Kooi, M.E. The increase in intramyocellular lipid content is a very early response to training. J. Clin. Endocrinol. Metab. 2003, 88, 1610-1616. [CrossRef] [PubMed]

114. Van Loon, L.J.; Koopman, R.; Manders, R.; van der Weegen, W.; van Kranenburg, G.P.; Keizer, H.A. Intramyocellular lipid content in type 2 diabetes patients compared with overweight sedentary men and highly trained endurance athletes. Am. J. Physiol. Endocrinol. Metab. 2004, 287, E558-E565. [CrossRef] [PubMed]

115. Dubé, J.J.; Amati, F.; Stefanovic-Racic, M.; Toledo, F.G.; Sauers, S.E.; Goodpaster, B.H. Exercise-induced alterations in intramyocellular lipids and insulin resistance: The athlete's paradox revisited. Am. J. Physiol. Endocrinol. Metab. 2008, 294, E882-E888. [CrossRef] [PubMed]

116. Dubé, J.J.; Amati, F.; Toledo, F.G.; Stefanovic-Racic, M.; Rossi, A.; Coen, P.; Goodpaster, B.H. Effects of weight loss and exercise on insulin resistance, and intramyocellular triacylglycerol, diacylglycerol and ceramide. Diabetologia 2011, 54, 1147-1156. [CrossRef] [PubMed]

117. Goodpaster, B.H.; He, J.; Watkins, S.; Kelley, D.E. Skeletal muscle lipid content and insulin resistance: Evidence for a paradox in endurance-trained athletes. J. Clin. Endocrinol. Metab. 2001, 86, 5755-5761. [CrossRef] [PubMed]

118. Morgan, T.E.; Short, F.A.; Cobb, L.A. Effect of long-term exercise on skeletal muscle lipid composition. Am. J. Physiol. 1969, 216, 82-86. [PubMed]

119. Pruchnic, R.; Katsiaras, A.; He, J.; Kelley, D.E.; Winters, C.; Goodpaster, B.H. Exercise training increases intramyocellular lipid and oxidative capacity in older adults. Am. J. Physiol. Endocrinol. Metab. 2004, 287, E857-E862. [CrossRef] [PubMed]

120. Van Loon, L.J.; Goodpaster, B.H. Increased intramuscular lipid storage in the insulin-resistant and endurance-trained state. Pflug. Arch. Eur. J. Physiol. 2006, 451, 606-616. [CrossRef] [PubMed]

121. Tarnopolsky, M.A.; Rennie, C.D.; Robertshaw, H.A.; Fedak-Tarnopolsky, S.N.; Devries, M.C.; Hamadeh, M.J. Influence of endurance exercise training and sex on intramyocellular lipid and mitochondrial ultrastructure, substrate use, and mitochondrial enzyme activity. Am. J. Physiol. Regul. Integr. Comp. Physiol. 2007, 292, R1271-R1278. [CrossRef] [PubMed]

122. Sullivan, S.; Kirk, E.P.; Mittendorfer, B.; Patterson, B.W.; Klein, S. Randomized trial of exercise effect on intrahepatic triglyceride content and lipid kinetics in nonalcoholic fatty liver disease. Hepatology 2012, 55, 1738-1745. [CrossRef] [PubMed]

123. Shah, K.; Stufflebam, A.; Hilton, T.N.; Sinacore, D.R.; Klein, S.; Villareal, D.T. Diet and exercise interventions reduce intrahepatic fat content and improve insulin sensitivity in obese older adults. Obesity 2009, 17, 2162-2168. [CrossRef] [PubMed] 
124. Johnson, N.A.; Sachinwalla, T.; Walton, D.W.; Smith, K.; Armstrong, A.; Thompson, M.W.; George, J. Aerobic exercise training reduces hepatic and visceral lipids in obese individuals without weight loss. Hepatology 2009, 50, 1105-1112. [CrossRef] [PubMed]

125. Pugh, C.J.; Spring, V.S.; Kemp, G.J.; Richardson, P.; Shojaee-Moradie, F.; Umpleby, A.M.; Green, D.J.; Cable, N.T.; Jones, H.; Cuthbertson, D.J. Exercise training reverses endothelial dysfunction in nonalcoholic fatty liver disease. Am. J. Physiol. Heart Circ. Physiol. 2014, 307, H1298-H1306. [CrossRef] [PubMed]

126. Schrauwen-Hinderling, V.B.; Hesselink, M.K.; Meex, R.; van der Made, S.; Schär, M.; Lamb, H.; Wildberger, J.E.; Glatz, J.; Snoep, G.; Kooi, M.E.; et al. Improved ejection fraction after exercise training in obesity is accompanied by reduced cardiac lipid content. J. Clin. Endocrinol. Metab. 2010, 95, 1932-1938. [CrossRef] [PubMed]

127. Essén-Gustavsson, B.; Tesch, P.A. Glycogen and triglyceride utilization in relation to muscle metabolic characteristics in men performing heavy-resistance exercise. Eur. J. Appl. Physiol. Occup. Physiol. 1990, 61, 5-10. [CrossRef] [PubMed]

128. Nurjhan, N.; Campbell, P.J.; Kennedy, F.P.; Miles, J.M.; Gerich, J.E. Insulin dose-response characteristics for suppression of glycerol release and conversion to glucose in humans. Diabetes 1986, 35, 1326-1331. [CrossRef] [PubMed]

129. Møller, N.; Jørgensen, J.O.; Schmitz, O.; Møller, J.; Christiansen, J.; Alberti, K.G.; Orskov, H. Effects of a growth hormone pulse on total and forearm substrate fluxes in humans. Am. J. Physiol. 1990, 258, E86-E91. [PubMed]

130. Hansen, T.K.; Gravholt, C.H.; Ørskov, H.; Rasmussen, M.H.; Christiansen, J.S.; Jørgensen, J.O. Dose dependency of the pharmacokinetics and acute lipolytic actions of growth hormone. J. Clin. Endocrinol. Metab. 2002, 87, 4691-4698. [CrossRef] [PubMed]

131. Møller, N.; Jørgensen, J.O. Effects of growth hormone on glucose, lipid, and protein metabolism in human subjects. Endocr. Rev. 2009, 30, 152-177. [CrossRef] [PubMed]

132. Romijn, J.A.; Coyle, E.F.; Sidossis, L.S.; Gastaldelli, A.; Horowitz, J.F.; Endert, E.; Wolfe, R.R. Regulation of endogenous fat and carbohydrate metabolism in relation to exercise intensity and duration. Am. J. Physiol. 1993, 265, E380-E391. [PubMed]

133. Standl, E.; Lotz, N.; Dexel, T.; Janka, H.U.; Kolb, H.J. Muscle triglycerides in diabetic subjects. Effect of insulin deficiency and exercise. Diabetologia 1980, 18, 463-469. [CrossRef] [PubMed]

134. Boon, H.; Blaak, E.E.; Saris, W.H.; Keizer, H.A.; Wagenmakers, A.J.; van Loon, L.J. Substrate source utilisation in long-term diagnosed type 2 diabetes patients at rest, and during exercise and subsequent recovery. Diabetologia 2007, 50, 103-112. [CrossRef] [PubMed]

135. Steffensen, C.H.; Roepstorff, C.; Madsen, M.; Kiens, B. Myocellular triacylglycerol breakdown in females but not in males during exercise. Am. J. Physiol. Endocrinol. Metab. 2002, 282, E634-E642. [CrossRef] [PubMed]

136. Roepstorff, C.; Donsmark, M.; Thiele, M.; Vistisen, B.; Stewart, G.; Vissing, K.; Schjerling, P.; Hardie, D.G.; Galbo, H.; Kiens, B. Sex differences in hormone-sensitive lipase expression, activity, and phosphorylation in skeletal muscle at rest and during exercise. Am. J. Physiol. Endocrinol. Metab. 2006, 291, E1106-E1114. [CrossRef] [PubMed]

137. Roepstorff, C.; Steffensen, C.H.; Madsen, M.; Stallknecht, B.; Kanstrup, I.L.; Richter, E.A.; Kiens, B. Gender differences in substrate utilization during submaximal exercise in endurance-trained subjects. Am. J. Physiol. Endocrinol. Metab. 2002, 282, E435-E447. [CrossRef] [PubMed]

138. Høeg, L.; Roepstorff, C.; Thiele, M.; Richter, E.A.; Wojtaszewski, J.F.; Kiens, B. Higher intramuscular triacylglycerol in women does not impair insulin sensitivity and proximal insulin signaling. J. Appl. Physiol. 2009, 107, 824-831. [CrossRef] [PubMed]

139. Sinha, R.; Dufour, S.; Petersen, K.F.; LeBon, V.; Enoksson, S.; Ma, Y.Z.; Savoye, M.; Rothman, D.L.; Shulman, G.I.; Caprio, S. Assessment of skeletal muscle triglyceride content by ${ }^{1} \mathrm{H}$ nuclear magnetic resonance spectroscopy in lean and obese adolescents: Relationships to insulin sensitivity, total body fat, and central adiposity. Diabetes 2002, 51, 1022-1027. [CrossRef] [PubMed]

140. Moro, C.; Galgani, J.E.; Luu, L.; Pasarica, M.; Mairal, A.; Bajpeyi, S.; Schmitz, G.; Langin, D.; Liebisch, G.; Smith, S.R. Influence of gender, obesity, and muscle lipase activity on intramyocellular lipids in sedentary individuals. J. Clin. Endocrinol. Metab. 2009, 94, 3440-3447. [CrossRef] [PubMed] 
141. Devries, M.C.; Lowther, S.A.; Glover, A.W.; Hamadeh, M.J.; Tarnopolsky, M.A. IMCL area density, but not IMCL utilization, is higher in women during moderate-intensity endurance exercise, compared with men. Am. J. Physiol. Regul. Integr. Comp. Physiol. 2007, 293, R2336-R2342. [CrossRef] [PubMed]

142. Santosa, S.; Jensen, M.D. The Sexual Dimorphism of Lipid Kinetics in Humans. Front. Endocrinol. 2015, 6, 103. [CrossRef] [PubMed]

143. Goldberg, I.J.; Merkel, M. Lipoprotein lipase: Physiology, biochemistry, and molecular biology. Front. Biosci. 2001, 6, D388-D405. [CrossRef] [PubMed]

144. Kersten, S. Physiological regulation of lipoprotein lipase. Biochim. Biophys. Acta 2014, 1841, 919-933. [CrossRef] [PubMed]

145. Ehehalt, R.; Füllekrug, J.; Pohl, J.; Ring, A.; Herrmann, T.; Stremmel, W. Translocation of long chain fatty acids across the plasma membrane-Lipid rafts and fatty acid transport proteins. Mol. Cell. Biochem. 2006, 284, 135-140. [CrossRef] [PubMed]

146. Jain, S.S.; Luiken, J.J.; Snook, L.A.; Han, X.X.; Holloway, G.P.; Glatz, J.F.; Bonen, A. Fatty acid transport and transporters in muscle are critically regulated by Akt2. FEBS Lett. 2015, 589, 2769-2775. [CrossRef] [PubMed]

147. Hamilton, J.A. Fatty acid transport: Difficult or easy? J. Lipid Res. 1998, 39, 467-481. [PubMed]

148. Alsted, T.J.; Nybo, L.; Schweiger, M.; Fledelius, C.; Jacobsen, P.; Zimmermann, R.; Zechner, R.; Kiens, B. Adipose triglyceride lipase in human skeletal muscle is upregulated by exercise training. Am. J. Physiol. Endocrinol. Metab. 2009, 296, E445-E453. [CrossRef] [PubMed]

149. Oscai, L.B.; Essig, D.A.; Palmer, W.K. Lipase regulation of muscle triglyceride hydrolysis. J. Appl. Physiol. 1990, 69, 1571-1577. [PubMed]

150. Roepstorff, C.; Vistisen, B.; Donsmark, M.; Nielsen, J.N.; Galbo, H.; Green, K.A.; Hardie, D.G.; Wojtaszewski, J.F.; Richter, E.A.; Kiens, B. Regulation of hormone-sensitive lipase activity and Ser563 and Ser565 phosphorylation in human skeletal muscle during exercise. J. Physiol. 2004, 560, 551-562. [CrossRef] [PubMed]

151. Watt, M.J.; Spriet, L.L. Regulation and role of hormone-sensitive lipase activity in human skeletal muscle. Proc. Nutr. Soc. 2004, 63, 315-322. [CrossRef] [PubMed]

152. Jocken, J.W.; Blaak, E.E. Catecholamine-induced lipolysis in adipose tissue and skeletal muscle in obesity. Physiol. Behav. 2008, 94, 219-230. [CrossRef] [PubMed]

153. Meex, R.C.; Schrauwen, P.; Hesselink, M.K. Modulation of myocellular fat stores: Lipid droplet dynamics in health and disease. Am. J. Physiol. Regul. Integr. Comp. Physiol. 2009, 297, R913-R924. [CrossRef] [PubMed]

154. Krssak, M.; Falk Petersen, K.; Dresner, A.; DiPietro, L.; Vogel, S.M.; Rothman, D.L.; Roden, M.; Shulman, G.I. Intramyocellular lipid concentrations are correlated with insulin sensitivity in humans: A $1 \mathrm{H}$ NMR spectroscopy study. Diabetologia 1999, 42, 113-116. [CrossRef] [PubMed]

155. Coen, P.M.; Dubé, J.J.; Amati, F.; Stefanovic-Racic, M.; Ferrell, R.E.; Toledo, F.G.; Goodpaster, B.H. Insulin resistance is associated with higher intramyocellular triglycerides in type I but not type II myocytes concomitant with higher ceramide content. Diabetes 2010, 59, 80-88. [CrossRef] [PubMed]

156. Samuel, V.T.; Shulman, G.I. Mechanisms for insulin resistance: Common threads and missing links. Cell 2012, 148, 852-871. [CrossRef] [PubMed]

157. Schrauwen, P.; Schrauwen-Hinderling, V.; Hoeks, J.; Hesselink, M.K. Mitochondrial dysfunction and lipotoxicity. Biochim. Biophys. Acta 2010, 1801, 266-271. [CrossRef] [PubMed]

158. Amati, F.; Dubé, J.J.; Alvarez-Carnero, E.; Chomentowski, P.; Coen, P.M.; Switzer, G.E.; Bickel, P.E.; Stefanovic-Racic, M.; Toledo, F.G.; Goodpaster, B.H. Skeletal muscle triglycerides, diacylglycerols, and ceramides in insulin resistance: Another paradox in endurance-trained athletes? Diabetes 2011, 60, 2588-2597. [CrossRef] [PubMed]

159. Badin, P.M.; Langin, D.; Moro, C. Dynamics of skeletal muscle lipid pools. Trends Endocrinol. Metab. 2013, 24, 607-615. [CrossRef] [PubMed]

160. Ong, J.P.; Pitts, A.; Younossi, Z.M. Increased overall mortality and liver-related mortality in non-alcoholic fatty liver disease. J. Hepatol. 2008, 49, 608-612. [CrossRef] [PubMed]

161. Dowman, J.K.; Tomlinson, J.W.; Newsome, P.N. Pathogenesis of non-alcoholic fatty liver disease. QJM 2010, 103, 71-83. [CrossRef] [PubMed]

162. Yang, W.S.; Va, P.; Bray, F.; Gao, S.; Gao, J.; Li, H.L.; Xiang, Y.B. The role of pre-existing diabetes mellitus on hepatocellular carcinoma occurrence and prognosis: A meta-analysis of prospective cohort studies. PLoS ONE 2011, 6, e27326. [CrossRef] [PubMed] 
163. Charlton, M. Nonalcoholic fatty liver disease: A review of current understanding and future impact. Clin. Gastroenterol. Hepatol. 2004, 2, 1048-1058. [CrossRef]

164. Petersen, K.F.; Dufour, S.; Savage, D.B.; Bilz, S.; Solomon, G.; Yonemitsu, S.; Cline, G.W.; Befroy, D.; Zemany, L.; Kahn, B.B.; et al. The role of skeletal muscle insulin resistance in the pathogenesis of the metabolic syndrome. Proc. Natl. Acad. Sci. USA 2007, 104, 12587-12594. [CrossRef] [PubMed]

165. Hwang, J.H.; Stein, D.T.; Barzilai, N.; Cui, M.H.; Tonelli, J.; Kishore, P.; Hawkins, M. Increased intrahepatic triglyceride is associated with peripheral insulin resistance: In vivo MR imaging and spectroscopy studies. Am. J. Physiol. Endocrinol. Metab. 2007, 293, E1663-E1669. [CrossRef] [PubMed]

166. Jeppesen, J.; Kiens, B. Regulation and limitations to fatty acid oxidation during exercise. J. Physiol. 2012, 590, 1059-1068. [CrossRef] [PubMed]

167. Donnelly, K.L.; Smith, C.I.; Schwarzenberg, S.J.; Jessurun, J.; Boldt, M.D.; Parks, E.J. Sources of fatty acids stored in liver and secreted via lipoproteins in patients with nonalcoholic fatty liver disease. J. Clin. Investig. 2005, 115, 1343-1351. [CrossRef] [PubMed]

168. Frayn, K.N. Adipose tissue as a buffer for daily lipid flux. Diabetologia 2002, 45, 1201-1210. [CrossRef] [PubMed]

169. Shulman, G.I. Ectopic fat in insulin resistance, dyslipidemia, and cardiometabolic disease. N. Engl. J. Med. 2014, 371, 1131-1141. [CrossRef] [PubMed]

170. Rijzewijk, L.J.; van der Meer, R.W.; Smit, J.W.; Diamant, M.; Bax, J.J.; Hammer, S.; Romijn, J.A.; de Roos, A.; Lamb, H.J. Myocardial steatosis is an independent predictor of diastolic dysfunction in type 2 diabetes mellitus. J. Am. Coll. Cardiol. 2008, 52, 1793-1799. [CrossRef] [PubMed]

171. Bugger, H.; Abel, E.D. Molecular mechanisms of diabetic cardiomyopathy. Diabetologia 2014, 57, 660-671. [CrossRef] [PubMed]

172. Mantovani, A.; Pernigo, M.; Bergamini, C.; Bonapace, S.; Lipari, P.; Pichiri, I.; Bertolini, L.; Valbusa, F.; Barbieri, E.; Zoppini, G.; et al. Nonalcoholic Fatty Liver Disease Is Independently Associated with Early Left Ventricular Diastolic Dysfunction in Patients with Type 2 Diabetes. PLoS ONE 2015, 10, e0135329. [CrossRef] [PubMed]

173. Granér, M.; Nyman, K.; Siren, R.; Pentikäinen, M.O.; Lundbom, J.; Hakkarainen, A.; Lauerma, K.; Lundbom, N.; Nieminen, M.S.; Taskinen, M.R. Ectopic fat depots and left ventricular function in nondiabetic men with nonalcoholic fatty liver disease. Circ. Cardiovasc. Imaging 2015, 8. [CrossRef] [PubMed]

174. Wolf, P.; Winhofer, Y.; Smajis, S.; Jankovic, D.; Anderwald, C.H.; Trattnig, S.; Luger, A.; Krebs, M.; Krššák, M. Pericardial- Rather than Intramyocardial Fat Is Independently Associated with Left Ventricular Systolic Heart Function in Metabolically Healthy Humans. PLoS ONE 2016, 11, e0151301. [CrossRef] [PubMed]

175. Bilet, L.; van de Weijer, T.; Hesselink, M.K.; Glatz, J.F.; Lamb, H.J.; Wildberger, J.; Kooi, M.E.; Schrauwen, P.; Schrauwen-Hinderling, V.B. Exercise-induced modulation of cardiac lipid content in healthy lean young men. Basic Res. Cardiol. 2011, 106, 307-315. [CrossRef] [PubMed]

176. Thamer, C.; Machann, J.; Bachmann, O.; Haap, M.; Dahl, D.; Wietek, B.; Tschritter, O.; Niess, A.; Brechtel, K.; Fritsche, A.; et al. Intramyocellular lipids: Anthropometric determinants and relationships with maximal aerobic capacity and insulin sensitivity. J. Clin. Endocrinol. Metab. 2003, 88, 1785-1791. [CrossRef] [PubMed]

177. Schrauwen-Hinderling, V.B.; Meex, R.C.; Hesselink, M.K.; van de Weijer, T.; Leiner, T.; Schär, M.; Lamb, H.J.; Wildberger, J.E.; Glatz, J.F.; Schrauwen, P.; et al. Cardiac lipid content is unresponsive to a physical activity training intervention in type 2 diabetic patients, despite improved ejection fraction. Cardiovasc. Diabetol. 2011, 10, 47. [CrossRef] [PubMed]

178. Finucane, F.M.; Sharp, S.J.; Purslow, L.R.; Horton, K.; Horton, J.; Savage, D.B.; Brage, S.; Besson, H.; de Lucia Rolfe, E.; Sleigh, A.; et al. The effects of aerobic exercise on metabolic risk, insulin sensitivity and intrahepatic lipid in healthy older people from the Hertfordshire Cohort Study: A randomised controlled trial. Diabetologia 2010, 53, 624-631. [CrossRef] [PubMed]

179. Taniguchi, H.; Tanisawa, K.; Sun, X.; Kubo, T.; Higuchi, M. Endurance Exercise Reduces Hepatic Fat Content and Serum Fibroblast Growth Factor 21 Levels in Elderly Men. J. Clin. Endocrinol. Metab. 2016, 101, 191-198. [CrossRef] [PubMed]

180. Lee, S.; Bacha, F.; Hannon, T.; Kuk, J.L.; Boesch, C.; Arslanian, S. Effects of aerobic versus resistance exercise without caloric restriction on abdominal fat, intrahepatic lipid, and insulin sensitivity in obese adolescent boys: A randomized, controlled trial. Diabetes 2012, 61, 2787-2795. [CrossRef] [PubMed] 
181. Cuthbertson, D.J.; Shojaee-Moradie, F.; Sprung, V.S.; Jones, H.; Pugh, C.J.; Richardson, P.; Kemp, G.J.; Barrett, M.; Jackson, N.C.; Thomas, E.L.; et al. Dissociation between exercise-induced reduction in liver fat and changes in hepatic and peripheral glucose homoeostasis in obese patients with non-alcoholic fatty liver disease. Clin. Sci. 2016, 130, 93-104. [CrossRef] [PubMed]

182. Hallsworth, K.; Thoma, C.; Hollingsworth, K.G.; Cassidy, S.; Anstee, Q.M.; Day, C.P.; Trenell, M.I. Modified high-intensity interval training reduces liver fat and improves cardiac function in non-alcoholic fatty liver disease: A randomized controlled trial. Clin. Sci. 2015, 129, 1097-1105. [CrossRef] [PubMed]

183. Hallsworth, K.; Fattakhova, G.; Hollingsworth, K.G.; Thoma, C.; Moore, S.; Taylor, R.; Day, C.P.; Trenell, M.I. Resistance exercise reduces liver fat and its mediators in non-alcoholic fatty liver disease independent of weight loss. Gut 2011, 60, 1278-1283. [CrossRef] [PubMed]

184. Kienesberger, P.C.; Pulinilkunnil, T.; Nagendran, J.; Dyck, J.R. Myocardial triacylglycerol metabolism. J. Mol. Cell. Cardiol. 2013, 55, 101-110. [CrossRef] [PubMed]

185. Lopaschuk, G.D.; Ussher, J.R.; Folmes, C.D.; Jaswal, J.S.; Stanley, W.C. Myocardial fatty acid metabolism in health and disease. Physiol. Rev. 2010, 90, 207-258. [CrossRef] [PubMed]

186. Brechtel, K.; Dahl, D.B.; Machann, J.; Bachmann, O.P.; Wenzel, I.; Maier, T.; Claussen, C.D.; Häring, H.U.; Jacob, S.; Schick, F. Fast elevation of the intramyocellular lipid content in the presence of circulating free fatty acids and hyperinsulinemia: A dynamic 1H-MRS study. Magn. Reson. Med. 2001, 45, 179-183. [CrossRef]

187. Hoeks, J.; Mensink, M.; Hesselink, M.K.; Ekroos, K.; Schrauwen, P. Long- and medium-chain fatty acids induce insulin resistance to a similar extent in humans despite marked differences in muscle fat accumulation. J. Clin. Endocrinol. Metab. 2012, 97, 208-216. [CrossRef] [PubMed]

188. Lee, S.; Boesch, C.; Kuk, J.L.; Arslanian, S. Effects of an overnight intravenous lipid infusion on intramyocellular lipid content and insulin sensitivity in African-American versus Caucasian adolescents. Metab. Clin. Exp. 2013, 62, 417-423. [CrossRef] [PubMed]

189. Fielding, B.A.; Callow, J.; Owen, R.M.; Samra, J.S.; Matthews, D.R.; Frayn, K.N. Postprandial lipemia: The origin of an early peak studied by specific dietary fatty acid intake during sequential meals. Am. J. Clin. Nutr. 1996, 63, 36-41. [PubMed]

190. Boden, G.; Lebed, B.; Schatz, M.; Homko, C.; Lemieux, S. Effects of acute changes of plasma free fatty acids on intramyocellular fat content and insulin resistance in healthy subjects. Diabetes 2001, 50, 1612-1617. [CrossRef] [PubMed]

191. Deldicque, L.; Van Proeyen, K.; Francaux, M.; Hespel, P. The unfolded protein response in human skeletal muscle is not involved in the onset of glucose tolerance impairment induced by a fat-rich diet. Eur. J. Appl. Physiol. 2011, 111, 1553-1558. [CrossRef] [PubMed]

192. Frøsig, C.; Roepstorff, C.; Brandt, N.; Maarbjerg, S.J.; Birk, J.B.; Wojtaszewski, J.F.; Richter, E.A.; Kiens, B. Reduced malonyl-CoA content in recovery from exercise correlates with improved insulin-stimulated glucose uptake in human skeletal muscle. Am. J. Physiol. Endocrinol. Metab. 2009, 296, E787-E795. [CrossRef] [PubMed]

193. Jazet, I.M.; Schaart, G.; Gastaldelli, A.; Ferrannini, E.; Hesselink, M.K.; Schrauwen, P.; Romijn, J.A.; Maassen, J.A.; Pijl, H.; Ouwens, D.M.; et al. Loss of 50\% of excess weight using a very low energy diet improves insulin-stimulated glucose disposal and skeletal muscle insulin signalling in obese insulin-treated type 2 diabetic patients. Diabetologia 2008, 51, 309-319. [CrossRef] [PubMed]

194. Petersen, K.F.; Dufour, S.; Morino, K.; Yoo, P.S.; Cline, G.W.; Shulman, G.I. Reversal of muscle insulin resistance by weight reduction in young, lean, insulin-resistant offspring of parents with type 2 diabetes. Proc. Natl. Acad. Sci. USA 2012, 109, 8236-8240. [CrossRef] [PubMed]

195. Lara-Castro, C.; Newcomer, B.R.; Rowell, J.; Wallace, P.; Shaughnessy, S.M.; Munoz, A.J.; Shiflett, A.M.; Rigsby, D.Y.; Lawrence, J.C.; Bohning, D.E.; et al. Effects of short-term very low-calorie diet on intramyocellular lipid and insulin sensitivity in nondiabetic and type 2 diabetic subjects. Metab. Clin. Exp. 2008, 57, 1-8. [CrossRef] [PubMed]

196. Coyle, E.F.; Jeukendrup, A.E.; Oseto, M.C.; Hodgkinson, B.J.; Zderic, T.W. Low-fat diet alters intramuscular substrates and reduces lipolysis and fat oxidation during exercise. Am. J. Physiol. Endocrinol. Metab. 2001, 280, E391-E398. [PubMed]

197. Van Herpen, N.A.; Schrauwen-Hinderling, V.B.; Schaart, G.; Mensink, R.P.; Schrauwen, P. Three weeks on a high-fat diet increases intrahepatic lipid accumulation and decreases metabolic flexibility in healthy overweight men. J. Clin. Endocrinol. Metab. 2011, 96, E691-E695. [CrossRef] [PubMed] 
198. Schrauwen-Hinderling, V.B.; Kooi, M.E.; Hesselink, M.K.; Moonen-Kornips, E.; Schaart, G.; Mustard, K.J.; Hardie, D.G.; Saris, W.H.; Nicolay, K.; Schrauwen, P. Intramyocellular lipid content and molecular adaptations in response to a 1-week high-fat diet. Obes. Res. 2005, 13, 2088-2094. [CrossRef] [PubMed]

199. Helge, J.W.; Watt, P.W.; Richter, E.A.; Rennie, M.J.; Kiens, B. Fat utilization during exercise: Adaptation to a fat-rich diet increases utilization of plasma fatty acids and very low density lipoprotein-triacylglycerol in humans. J. Physiol. 2001, 537, 1009-1020. [CrossRef] [PubMed]

200. Helge, J.W.; Wulff, B.; Kiens, B. Impact of a fat-rich diet on endurance in man: Role of the dietary period. Med. Sci. Sports Exerc. 1998, 30, 456-461. [CrossRef] [PubMed]

201. Vogt, M.; Puntschart, A.; Howald, H.; Mueller, B.; Mannhart, C.; Gfeller-Tuescher, L.; Mullis, P.; Hoppeler, H. Effects of dietary fat on muscle substrates, metabolism, and performance in athletes. Med. Sci. Sports Exerc. 2003, 35, 952-960. [CrossRef] [PubMed]

202. Yoshimura, E.; Kumahara, H.; Tobina, T.; Matsuda, T.; Ayabe, M.; Kiyonaga, A.; Anzai, K.; Higaki, Y.; Tanaka, H. Lifestyle intervention involving calorie restriction with or without aerobic exercise training improves liver fat in adults with visceral adiposity. J. Obes. 2014, 2014. [CrossRef] [PubMed]

203. Wong, V.W.; Chan, R.S.; Wong, G.L.; Cheung, B.H.; Chu, W.C.; Yeung, D.K.; Chim, A.M.; Lai, J.W.; Li, L.S.; Sea, M.M.; et al. Community-based lifestyle modification programme for non-alcoholic fatty liver disease: A randomized controlled trial. J. Hepatol. 2013, 59, 536-542. [CrossRef] [PubMed]

204. Larson-Meyer, D.E.; Heilbronn, L.K.; Redman, L.M.; Newcomer, B.R.; Frisard, M.I.; Anton, S.; Smith, S.R.; Alfonso, A.; Ravussin, E. Effect of calorie restriction with or without exercise on insulin sensitivity, beta-cell function, fat cell size, and ectopic lipid in overweight subjects. Diabetes Care 2006, 29, 1337-1344. [CrossRef] [PubMed]

205. Petersen, K.F.; Dufour, S.; Befroy, D.; Lehrke, M.; Hendler, R.E.; Shulman, G.I. Reversal of nonalcoholic hepatic steatosis, hepatic insulin resistance, and hyperglycemia by moderate weight reduction in patients with type 2 diabetes. Diabetes 2005, 54, 603-608. [CrossRef] [PubMed]

206. Hammer, S.; Snel, M.; Lamb, H.J.; Jazet, I.M.; van der Meer, R.W.; Pijl, H.; Meinders, E.A.; Romijn, J.A.; de Roos, A.; Smit, J.W. Prolonged caloric restriction in obese patients with type 2 diabetes mellitus decreases myocardial triglyceride content and improves myocardial function. J. Am. Coll. Cardiol. 2008, 52, 1006-1012. [CrossRef] [PubMed]

207. Lim, E.L.; Hollingsworth, K.G.; Aribisala, B.S.; Chen, M.J.; Mathers, J.C.; Taylor, R. Reversal of type 2 diabetes: Normalisation of $\beta$ cell function in association with decreased pancreas and liver triacylglycerol. Diabetologia 2011, 54, 2506-2514. [CrossRef] [PubMed]

208. Sobrecases, H.; Lê, K.A.; Bortolotti, M.; Schneiter, P.; Ith, M.; Kreis, R.; Boesch, C.; Tappy, L. Effects of short-term overfeeding with fructose, fat and fructose plus fat on plasma and hepatic lipids in healthy men. Diabetes Metab. 2010, 36, 244-246. [CrossRef] [PubMed]

209. Westerbacka, J.; Lammi, K.; Häkkinen, A.M.; Rissanen, A.; Salminen, I.; Aro, A.; Yki-Järvinen, H. Dietary fat content modifies liver fat in overweight nondiabetic subjects. J. Clin. Endocrinol. Metab. 2005, 90, 2804-2809. [CrossRef] [PubMed]

210. Rosqvist, F.; Iggman, D.; Kullberg, J.; Cedernaes, J.; Johansson, H.E.; Larsson, A.; Johansson, L.; Ahlström, H.; Arner, P.; Dahlman, I.; et al. Overfeeding polyunsaturated and saturated fat causes distinct effects on liver and visceral fat accumulation in humans. Diabetes 2014, 63, 2356-2368. [CrossRef] [PubMed]

211. Kirk, E.; Reeds, D.N.; Finck, B.N.; Mayurranjan, S.M.; Patterson, B.W.; Klein, S. Dietary fat and carbohydrates differentially alter insulin sensitivity during caloric restriction. Gastroenterology 2009, 136, 1552-1560. [CrossRef] [PubMed]

212. Browning, J.D.; Baker, J.A.; Rogers, T.; Davis, J.; Satapati, S.; Burgess, S.C. Short-term weight loss and hepatic triglyceride reduction: Evidence of a metabolic advantage with dietary carbohydrate restriction. Am. J. Clin. Nutr. 2011, 93, 1048-1052. [CrossRef] [PubMed]

213. Haufe, S.; Engeli, S.; Kast, P.; Böhnke, J.; Utz, W.; Haas, V.; Hermsdorf, M.; Mähler, A.; Wiesner, S.; Birkenfeld, A.L.; et al. Randomized comparison of reduced fat and reduced carbohydrate hypocaloric diets on intrahepatic fat in overweight and obese human subjects. Hepatology 2011, 53, 1504-1514. [CrossRef] [PubMed]

214. Brøns, C.; Jensen, C.B.; Storgaard, H.; Hiscock, N.J.; White, A.; Appel, J.S.; Jacobsen, S.; Nilsson, E.; Larsen, C.M.; Astrup, A.; et al. Impact of short-term high-fat feeding on glucose and insulin metabolism in young healthy men. J. Physiol. 2009, 587, 2387-2397. [CrossRef] [PubMed] 
215. Maersk, M.; Belza, A.; Stødkilde-Jørgensen, H.; Ringgaard, S.; Chabanova, E.; Thomsen, H.; Pedersen, S.B.; Astrup, A.; Richelsen, B.; Richelsen, B. Sucrose-sweetened beverages increase fat storage in the liver, muscle, and visceral fat depot: A 6-mo randomized intervention study. Am. J. Clin. Nutr. 2012, 95, 283-289. [CrossRef] [PubMed]

216. Assy, N.; Nasser, G.; Kamayse, I.; Nseir, W.; Beniashvili, Z.; Djibre, A.; Grosovski, M. Soft drink consumption linked with fatty liver in the absence of traditional risk factors. Can. J. Gastroenterol. 2008, 22, 811-816. [CrossRef] [PubMed]

217. Ngo Sock, E.T.; Lê, K.A.; Ith, M.; Kreis, R.; Boesch, C.; Tappy, L. Effects of a short-term overfeeding with fructose or glucose in healthy young males. Br. J. Nutr. 2010, 103, 939-943. [CrossRef] [PubMed]

218. Lê, K.A.; Ith, M.; Kreis, R.; Faeh, D.; Bortolotti, M.; Tran, C.; Boesch, C.; Tappy, L. Fructose overconsumption causes dyslipidemia and ectopic lipid deposition in healthy subjects with and without a family history of type 2 diabetes. Am. J. Clin. Nutr. 2009, 89, 1760-1765. [CrossRef] [PubMed]

219. Lecoultre, V.; Egli, L.; Carrel, G.; Theytaz, F.; Kreis, R.; Schneiter, P.; Boss, A.; Zwygart, K.; Lê, K.A.; Bortolotti, M.; et al. Effects of fructose and glucose overfeeding on hepatic insulin sensitivity and intrahepatic lipids in healthy humans. Obesity 2013, 21, 782-785. [CrossRef] [PubMed]

220. Theytaz, F.; Noguchi, Y.; Egli, L.; Campos, V.; Buehler, T.; Hodson, L.; Patterson, B.W.; Nishikata, N.; Kreis, R.; Mittendorfer, B.; et al. Effects of supplementation with essential amino acids on intrahepatic lipid concentrations during fructose overfeeding in humans. Am. J. Clin. Nutr. 2012, 96, 1008-1016. [CrossRef] [PubMed]

221. Campos, V.; Despland, C.; Brandejsky, V.; Kreis, R.; Schneiter, P.; Chiolero, A.; Boesch, C.; Tappy, L. Sugarand artificially sweetened beverages and intrahepatic fat: A randomized controlled trial. Obesity 2015, 23, 2335-2239. [CrossRef] [PubMed]

222. Faeh, D.; Minehira, K.; Schwarz, J.M.; Periasamy, R.; Park, S.; Tappy, L. Effect of fructose overfeeding and fish oil administration on hepatic de novo lipogenesis and insulin sensitivity in healthy men. Diabetes 2005, 54, 1907-1913. [CrossRef] [PubMed]

223. Nseir, W.; Nassar, F.; Assy, N. Soft drinks consumption and nonalcoholic fatty liver disease. World J. Gastroenterol. 2010, 16, 2579-2588. [CrossRef] [PubMed]

224. Rutledge, A.C.; Adeli, K. Fructose and the metabolic syndrome: Pathophysiology and molecular mechanisms. Nutr. Rev. 2007, 65, S13-S23. [CrossRef] [PubMed]

225. McDevitt, R.M.; Bott, S.J.; Harding, M.; Coward, W.A.; Bluck, L.J.; Prentice, A.M. De novo lipogenesis during controlled overfeeding with sucrose or glucose in lean and obese women. Am. J. Clin. Nutr. 2001, 74, 737-746. [PubMed]

226. Lê, K.A.; Faeh, D.; Stettler, R.; Ith, M.; Kreis, R.; Vermathen, P.; Boesch, C.; Ravussin, E.; Tappy, L. A 4-wk high-fructose diet alters lipid metabolism without affecting insulin sensitivity or ectopic lipids in healthy humans. Am. J. Clin. Nutr. 2006, 84, 1374-1379. [PubMed]

227. Johnston, R.D.; Stephenson, M.C.; Crossland, H.; Cordon, S.M.; Palcidi, E.; Cox, E.F.; Taylor, M.A.; Aithal, G.P.; Macdonald, I.A. No difference between high-fructose and high-glucose diets on liver triacylglycerol or biochemistry in healthy overweight men. Gastroenterology 2013, 145, 1016-1025. [CrossRef] [PubMed]

228. Bortolotti, M.; Maiolo, E.; Corazza, M.; van Dijke, E.; Schneiter, P.; Boss, A.; Carrel, G.; Giusti, V.; Lê, K.A.; Quo Chong, D.G.; et al. Effects of a whey protein supplementation on intrahepatocellular lipids in obese female patients. Clin. Nutr. 2011, 30, 494-498. [CrossRef] [PubMed]

229. Hammer, S.; van der Meer, R.W.; Lamb, H.J.; de Boer, H.H.; Bax, J.J.; de Roos, A.; Romijn, J.A.; Smit, J.W. Short-term flexibility of myocardial triglycerides and diastolic function in patients with type 2 diabetes mellitus. Am. J. Physiol. Endocrinol. Metab. 2008, 295, E714-E718. [CrossRef] [PubMed]

230. Abdesselam, I.; Dutour, A.; Kober, F.; Ancel, P.; Bege, T.; Darmon, P.; Lesavre, N.; Bernard, M.; Gaborit, B. Time Course of Change in Ectopic Fat Stores after Bariatric Surgery. J. Am. Coll. Cardiol. 2016, 67, 117-119. [CrossRef] [PubMed]

231. Garg, A. Lipodystrophies: Genetic and acquired body fat disorders. J. Clin. Endocrinol. Metab. 2011, 96, 3313-3325. [CrossRef] [PubMed]

232. Chalasani, N.; Younossi, Z.; Lavine, J.E.; Diehl, A.M.; Brunt, E.M.; Cusi, K.; Charlton, M.; Sanyal, A.J. The diagnosis and management of non-alcoholic fatty liver disease: Practice guideline by the American Gastroenterological Association, American Association for the Study of Liver Diseases, and American College of Gastroenterology. Gastroenterology 2012, 142, 1592-1609. [CrossRef] [PubMed] 
233. Lanktree, M.B.; Johansen, C.T.; Joy, T.R.; Hegele, R.A. A translational view of the genetics of lipodystrophy and ectopic fat deposition. Prog. Mol. Biol. Trans. Sci. 2010, 94, 159-196.

234. Tsoukas, M.A.M.C. Lipodystrophy syndromes. In Endocrinology: Adult and Pediatric, 7th ed.; Jameson, J.L., de Groot, L.J., Eds.; Saunders: Philadelphia, PA, USA, 2015.

235. Haque, W.A.; Shimomura, I.; Matsuzawa, Y.; Garg, A. Serum adiponectin and leptin levels in patients with lipodystrophies. J. Clin. Endocrinol. Metab. 2002, 87, 2395. [CrossRef] [PubMed]

236. Petersen, K.F.; Oral, E.A.; Dufour, S.; Befroy, D.; Ariyan, C.; Yu, C.; Cline, G.W.; DePaoli, A.M.; Taylor, S.I.; Gorden, P.; et al. Leptin reverses insulin resistance and hepatic steatosis in patients with severe lipodystrophy. J. Clin. Investig. 2002, 109, 1345-1350. [CrossRef] [PubMed]

237. Simha, V.; Szczepaniak, L.S.; Wagner, A.J.; DePaoli, A.M.; Garg, A. Effect of leptin replacement on intrahepatic and intramyocellular lipid content in patients with generalized lipodystrophy. Diabetes Care 2003, 26, 30-35. [CrossRef] [PubMed]

238. Safar Zadeh, E.; Lungu, A.O.; Cochran, E.K.; Brown, R.J.; Ghany, M.G.; Heller, T.; Kleiner, D.E.; Gorden, P. The liver diseases of lipodystrophy: The long-term effect of leptin treatment. J. Hepatol. 2013, 59, 131-137. [CrossRef] [PubMed]

239. Charlton, M.R.; Burns, J.M.; Pedersen, R.A.; Watt, K.D.; Heimbach, J.K.; Dierkhising, R.A. Frequency and outcomes of liver transplantation for nonalcoholic steatohepatitis in the United States. Gastroenterology 2011, 141, 1249-1253. [CrossRef] [PubMed]

240. Sanyal, A.J.; Chalasani, N.; Kowdley, K.V.; McCullough, A.; Diehl, A.M.; Bass, N.M.; Neuschwander-Tetri, B.A.; Lavine, J.E.; Tonascia, J.; Unalp, A.; et al. Pioglitazone, vitamin E.; or placebo for nonalcoholic steatohepatitis. N. Engl. J. Med. 2010, 362, 1675-1685. [CrossRef] [PubMed]

241. Neuschwander-Tetri, B.A.; Loomba, R.; Sanyal, A.J.; Lavine, J.E.; Van Natta, M.L.; Abdelmalek, M.F.; Chalasani, N.; Dasarathy, S.; Diehl, A.M.; Hameed, B.; et al. Farnesoid X nuclear receptor ligand obeticholic acid for non-cirrhotic, non-alcoholic steatohepatitis (FLINT): A multicentre, randomised, placebo-controlled trial. Lancet 2015, 385, 956-965. [CrossRef]

242. Dutour, A.; Abdesselam, I.; Ancel, P.; Kober, F.; Mrad, G.; Darmon, P.; Ronsin, O.; Pradel, V.; Lesavre, N.; Martin, J.C.; et al. Exenatide decreases liver fat content and epicardial adipose tissue in patients with obesity and type 2 diabetes: A prospective randomized clinical trial using magnetic resonance imaging and spectroscopy. Diabetes Obes. Metab. 2016, 18, 882-891. [CrossRef] [PubMed]

243. Armstrong, M.J.; Gaunt, P.; Aithal, G.P.; Barton, D.; Hull, D.; Parker, R.; Hazlehurst, J.M.; Guo, K.; LEAN trial team; Abouda, G.; et al. Liraglutide safety and efficacy in patients with non-alcoholic steatohepatitis (LEAN): A multicentre, double-blind, randomised, placebo-controlled phase 2 study. Lancet 2016, 387, 679-690. [CrossRef]

244. Blackett, P.R.; Sanghera, D.K. Genetic determinants of cardiometabolic risk: A proposed model for phenotype association and interaction. J. Clin. Lipidol. 2013, 7, 65-81. [CrossRef] [PubMed]

(C) 2016 by the authors; licensee MDPI, Basel, Switzerland. This article is an open access article distributed under the terms and conditions of the Creative Commons Attribution (CC-BY) license (http://creativecommons.org/licenses/by/4.0/). 